\title{
PLAGL1 gene function during hesearch Paper PLAGL1 gene function during hepatoma cells proliferation
}

\author{
Ana F. Vega-Benedetti ${ }^{1}$, Cinthia N. Saucedo ${ }^{1}$, Patrizia Zavattari ${ }^{2}$, Roberta Vanni ${ }^{2}$, \\ Felix Royo ${ }^{3}$, Francisco Llavero ${ }^{4,5,6}$, José L. Zugaza ${ }^{4,5,6}$ and Luis A. Parada ${ }^{1}$ \\ ${ }^{1}$ Institute of Experimental Pathology, CONICET-UNSa, Salta, Argentina \\ ${ }^{2}$ Biochemistry, Biology and Genetics Unit, Department of Biomedical Sciences, University of Cagliari, Cittadella Universitaria \\ di Monserrato SP 8, Monserrato, Cagliari, Italy \\ ${ }^{3}$ CIC BioGUNE-CIBERehd, Bizkaia Technology Park, Derio, Spain \\ ${ }^{4}$ Achucarro Basque Center for Neuroscience, UPV/EHU Technology Park, Leioa, Spain \\ ${ }^{5}$ Department of Genetics, Physical Anthropology and Animal Physiology, Faculty of Medicine and Dentistry, University of the \\ Basque Country, Leioa, Spain \\ ${ }^{6}$ IKERBASQUE, Basque Foundation for Science, Bilbao, Spain
}

Correspondence to: Luis A. Parada, email: Iparada@unsa.edu.ar

Keywords: PLAGL1; hepatocellular carcinoma; cell proliferation; chromosome; methylation

Received: March 26, $2018 \quad$ Accepted: July 31, $2018 \quad$ Published: August 28, 2018

Copyright: Vega-Benedetti et al. This is an open-access article distributed under the terms of the Creative Commons Attribution License 3.0 (CC BY 3.0), which permits unrestricted use, distribution, and reproduction in any medium, provided the original author and source are credited.

\section{ABSTRACT}

Hepatocellular carcinoma develops as a multistep process, in which cell cycle deregulation is a central feature, resulting in unscheduled proliferation. The PLAGL1 gene encodes a homonym zinc finger protein that is involved in cell-proliferation control. We determined the genomic profile and the transcription and expression level of PLAGL1, simultaneously with that of its molecular partners p53, PPARY and $p 21$, in cell-lines derived from patients with liver cancer, during in vitro cell growth. Our investigations revealed that genomic and epigenetic changes of PLAGL1 are also present in hepatoma cell-lines. Transcription of PLAGL1 in tumor cells is significantly lower than in normal fibroblasts, but no significant differences in terms of protein expression were detected between these two cell-types, indicating that there is not a direct relationship between the gene transcriptional activity and protein expression. RT-PCR analyses on normal fibroblasts, used as control, also showed that PLAGL1 and p53 genes transcription occurs as an apparent orchestrated process during normal cells proliferation, which gets disturbed in cancer cells. Furthermore, abnormal trafficking of the PLAGL1 protein may occur in hepatocarcinogenesis.

\section{INTRODUCTION}

Hepatocellular carcinoma (HCC) is the sixth most common cancer and the third cause of death cancer worldwide. HCC is widely distributed around the world, presenting higher incidence in sub-Saharan Africa and Eastern Asia than Northern Europe, Oceania and America [1]. This uneven geographical distribution is closely related to that of the risk factors which vary among regions. For instance, the hepatitis $\mathrm{B}$ and $\mathrm{C}$ virus infections are common in Asia and Japan, respectively, whereas obesity and non-alcoholic liver disease lead to an increased incidence of HCC in United States and other western countries [2].

HCC develops as a multistep process, in which multiple factors play a role creating the conditions for malignant transformation. For example, hepatitis B or C viruses infection lead to liver damage and regeneration events, in which the persistent inflammation and oxidative stress favour the occurrence of genomic instability leading to the accumulation of genetic and epigenetic alterations that are a hallmark of tumorigenesis $[3,4]$. Cell proliferation is regulated by a complex network of signalling pathways, such as HGF/MET, Wnt/ $\beta$-catenin 
and p53, among others $[5,6]$. Structural and/or functional alterations of proteins that participate in these pathways, leading to cell-cycle deregulation are frequently found in HCC cells [7]. For example, mutations in the CTNNB1 gene, encoding for an abnormal $\beta$-Catenin protein, have been found in about $30 \%$ of HCC biopsies analyzed by Schulze et al. in 2016 [8]. While in vitro studies, using the HepG2, SkHep1 and Huh7 cell lines derived from human heptomas demonstrated that down-regulation of the COMMD7 gene and the treatment with isocorydine and interferons favour inhibition of cell proliferation and induction of apoptosis [9-11].

The PLAGL1 (Pleiomorphic Adenoma GeneLike 1) gene maps on chromosome 6q24 [12], and it encodes a homonym zinc finger protein that functions as a transcription factor and as a cofactor of other proteins involved in cell cycle control [13]. PLAGL1 carries on its activities through convergent mechanisms. On one hand, it interacts with p53 and this heterodimer induces the expression of the receptor for pituitary adenylyl cyclase-activating peptide (PACAP $\left.{ }_{1}-\mathrm{R}\right)$. The binding peptides to $\mathrm{PACAP}_{1}-\mathrm{R}$ induce gene transcription through AP-1, essential for proliferation and differentiation of various cell types [14]. Moreover, PLAGL1 and p53 bind as a complex to the promoter of $p 21$ gene, an important cell cycle regulator; favouring its transcription and leading to cell cycle arrest in G1 phase $[15,16]$. On the other hand, PLAGL1 induces the expression of PPAR $\gamma$ that inhibits cell cycle progression through p2 1 induction and metastatic activity through the regulation of matrix metalloproteinases expression [17, 18]. It was demonstrated that genomic changes such as loss of heterozygosity ( $\mathrm{LOH})$ and hypermethylation of the $\mathrm{P} 1$ promoter of the PLAGL1 gene are frequently observed in several types of cancer such as pheochromocytoma [19], ovarian cancer [20], breast cancer [21], pituitary adenomas [22] and hemangioblastoma [23], and in tumor cell lines including breast cancer cell lines [21]. Moreover, altered expression of PLAGL1, mainly reduced, was revealed in colorectal cancer and non-functioning pituitary adenoma $[24,25]$. Midorikawa et al. examined samples of HCC, and found that $\mathrm{LOH}$ at chromosome $6 \mathrm{q}$, hypermethylation of PLAGL1 promoter at the remaining allele and low RNA expression levels were present in their series [26]. Since it was first described, the gene has been considered a tumor suppressor gene (TSG) [27], and all this evidence provided support for such classification. However, overexpression of PLAGL1 was detected in some human neoplasms such as glioma and clear cell renal cell carcinoma suggesting an oncogenic function, as well $[28,29]$.

In the present study we investigated the profile of 6q2 aberrations, where PLAGL1 gene maps, in four hepatoma cell-lines and the transcription and protein expression level of PLAGL1 and its molecular partners $p 53, P P A R \gamma$ and $p 21$ during in vitro cell-proliferation. Our data confirm that genomic and epigenetic changes of
PLAGL1 are also present in HCC cell-lines. Furthermore, we found that there is not a direct relationship between the gene transcriptional activity and protein expression during cell-proliferation and that abnormal subcellular localization of the PLAGL1 protein may occur during hepatocarcinogenesis.

\section{RESULTS}

\section{Array-CGH analysis}

Except for PLC/PRF/5 cells, all hepatoma celllines exhibited an aberrant genomic profile at 6q24.2, where the PLAGL1 gene maps. Huh7 cells have losses of genetic material from almost the whole chromosome 6, but gains of the chromosome region 6q22.2. SkHep1 cells showed losses of genetic material from the long arm of chromosome 6 , and a specific amplification of $6 \mathrm{q} 25.2$. These cells also have gains of the short arm of the chromosome 6 , but with punctual deletions at $6 \mathrm{p} 21.32$ and $6 \mathrm{p} 21.33$. Regarding the region $6 \mathrm{q} 24.2$, the log-ratios for Huh7 and SKHep1 cells were -1.368 and -0.582 , respectively, indicating that both tumor cell lines presented losses at the locus of PLAGL1 gene. On the contrary, HepG2 cells exhibited gains of the short arm of chromosome 6 , while the long arm presented a punctual loss at q14 and gains of the region q22-qter. This cell line showed positive values of logratio $(\approx 0.500)$ of the probes used specifically for the fragment $6 \mathrm{q} 24.2$ where PLAGL1 maps, thus indicating gain of material. Finally, the hepatoma cell line PLC/PRF/5, apart from few punctual gains and losses in other chromosomes, did not present changes at chromosome 6 (Figure 1 and Table 1).

The genome regions where the p53, PPARy and $p 21$ genes map were also studied by aCGH in the four cell lines. The tumor suppressor gene $p 53$ maps on chromosome $17 \mathrm{p} 13.1$ and the analysis demonstrated that this region is amplified in SkHep1 (logratio value $=0.398$ ), while in the other hepatoma cell-lines Huh7, HepG2 and PLC/PRF/5 no abnormalities were detected. Regarding the PPARy gene (3p25.2), HepG2, Huh7 and $\mathrm{PLC} / \mathrm{PRF} / 5$ did not exhibit quantitative changes, but the analysis of SkHep1 revealed loss at this region (logratio value $=-0.571)$. The data obtained for the region where the $p 21$ gene maps (6p21.31) are consistent with gains of genetic material in the HepG2 and SkHep1 cell-lines (logratios values $=0.517$ and 0.277 , respectively). In PLC/ $\mathrm{PRF} / 5$ cells aberrations at $6 \mathrm{p} 2$ were not detected, while in Huh7 a logratio value of -1.277 indicates losses of this chromosome region (Table 1).

Out of 11 tissue-samples from patients with primary liver tumors, seven yielded quality DNA for aCGH. The analysis of quantitative genomic alterations revealed log-ratios compatible with losses at 6q24.2 (PLAGL1) in three of them: H008, H010 and H005 (Table 2). While all analyzed tumor samples did not present abnormalities 
on the chromosome regions where the $p 21$ and $p 53$ genes map.

\section{Methyl specific PCR}

To study the methylation state of the $\mathrm{P} 1$ promoter of the PLAGL1 gene we performed MS-PCR. All cell lines presented a fraction of DNA methylated and another unmethylated. However, conspicuous differences in terms of intensity of the bands corresponding to these fractions were observed after gel electrophoresis in three cell lines. HepG2 was the only cell line in which the DNA-band of methylated P1 promoter was rather similar to that of unmethylated promoter, whereas in the SkHep1, Huh7 and PLC/PRF/5 cell lines the methylated DNA fraction was much more intense than the unmethylated fractions (Figure 2).

\section{Proliferation assays and flow cytometry}

To estimate the proliferation capacity of the celllines, the number of cells at different time points during culturing was determined, and used to calculate the doubling time (DT). Among tumor cell-lines, PLC/PRF/5 cells were the most prolifertive; our DT calculation showed that these cells duplicated their number after $23 \mathrm{~h}$

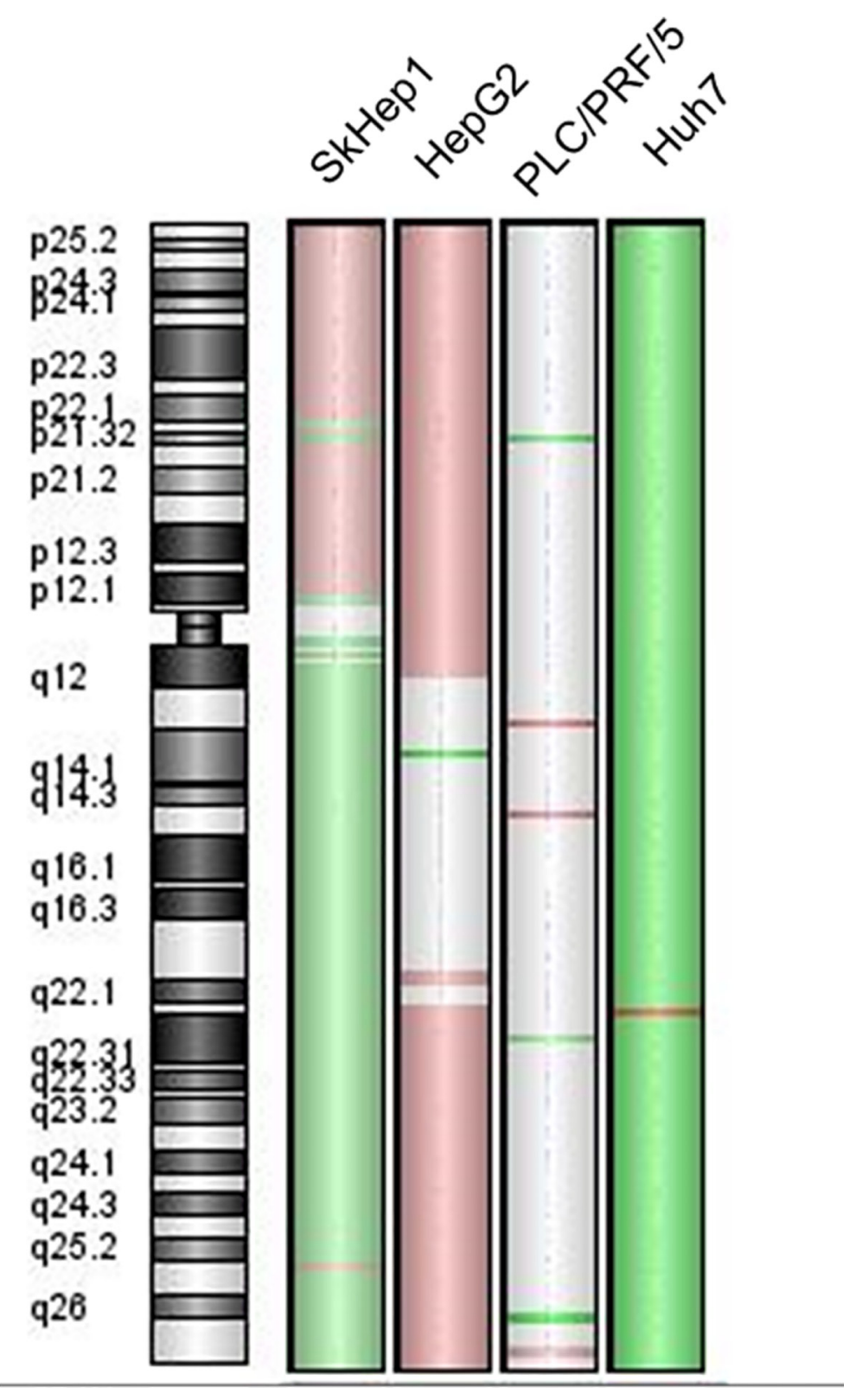

Figure 1: Chromosome 6 genomic profile of the cell-lines SkHep1, HepG2, PLC/PRF/5 and Huh7. The green colour on the chromosome ideogram indicates loss of the fragment, the red indicates gain and the grey indicates a balanced status. 
Table 1: Genomic profile of the chromosome regions where the PLAGL1, p53, PPARy and $p 21$ genes map in four hepatoma cell-lines

\begin{tabular}{lcccc}
\hline & \multicolumn{4}{c}{ Gene } \\
\cline { 2 - 5 } Cell line & PLAGL1 & $\boldsymbol{p 5 3}$ & PPARy & p21 \\
\hline HepG2 & 0.507 & 0.000 & 0.000 & 0.517 \\
SkHep1 & -0.582 & 0.398 & -0.571 & 0.277 \\
Huh7 & -1.368 & 0.000 & 0.000 & -1.277 \\
PLC/PRF/5 & 0.000 & 0.000 & 0.000 & 0.000 \\
\hline
\end{tabular}

Positive values of the log-ratios indicate gain of genetic material, negatives indicate losses and 0.000 means absense of genomic abnormalities.

Table 2: Summary of the aCGH and in situ PLAGL1 and p21 proteins expression data from primary liver tumors

\begin{tabular}{lcccc}
\hline & & \multicolumn{2}{c}{ aCGH } & \multicolumn{2}{c}{ Immunohistochemistry } \\
\cline { 3 - 5 } Sample & Diagnostic & PLAGL1 Logratio & PLAGL1 & p21 \\
\hline H001 & HCC & 0.000 & - & - \\
H002 & HCC & NA & + & - \\
H003 & HCC & 0.000 & + & - \\
H004 & HCC & -0.472 & +++ & ++ \\
H005 & HCC & 0.000 & + & - \\
H012 & HCC & NA & ++ & + \\
H013 & HCC & -0.422 & ++ & + \\
H008 & FNH & 0.000 & + & - \\
H009 & CCC & -0.605 & ++ & + \\
H010 & HAC & NA & +++ & ++ \\
H011 & HAC & NA & +++ & - \\
H015 & Normal tissue & & +++ \\
\hline
\end{tabular}

The expression of PLAGL1 and p21 was evaluated in eleven tumor samples and one from normal liver tissue. Except two tumors, all exhibited lower level of PLAGL1, while expression of p21 in all of them was absent or lower than in normal liver tissue. HCC: hepatocellular carcinoma; FNH: focal nodular hyperplasia; CCC: cholangiocellular carcinoma; HAC: Hepatoadenocarcinoma. Negative values of the logratios indicate losses of genetic material, 0.000 means absense of genomic abnormalities and NA stands for not analyzed. Score of each marker was calculated as described in Materials and Methods: strong expression $(+++)$, moderate expression $(++)$, weak expression $(+)$ and negative expression $(-)$.

of culture. SkHep1 cells were also highly proliferative $(\mathrm{DT}=26 \mathrm{~h})$, both cell-lines reached confluence faster than HepG2 and Huh7 whose DT were $29 \mathrm{~h}$ and $27 \mathrm{~h}$, respectively. Fibroblasts had low proliferation capacity compared to tumor cells, and this is reflected by the high DT (59 h) (Figure 3A). To further study the proliferation capacity of the tumor cells, the amount of cells in the different phases of the cell cycle were determined by flow cytometry. The percentage of cells in the G2/M phase of the cell cycle increased from the beginning of the experiment $(\mathrm{T}=0 \mathrm{~h})$ until $48 \mathrm{~h}$ in culture, and from this time-point forward the fraction of cells in this stage decreased in all cell-lines. However, this analysis showed that during the entire assay the tumor cell-lines always presented higher percentage of cells in the G2/M phase than non-tumoral fibroblasts. Accordingly, the amount of fibroblasts in G1 phase was always higher than tumor cells (Figure 3B-3F).

\section{PLAGL1, p53 and PPARy transcription}

mRNA levels of the PLAGL1, p53 and PPARy genes in all cell types and at the different time points during proliferation were estimated by quantitative RTPCR, and expressed respect to the level of the PPIA gene. Then we compared the transcript levels of PLAGL1, p53 and PPARy of each tumor cell line with those obtained for fibroblasts at the same time point of the proliferation curve. This study showed that PLAGL1 and $p 53$ transcript levels were in general significantly lower in all HCC 
cell-lines compared to fibroblasts, except for $p 53$ transcript level in HepG2 and Huh7 cells at $48 \mathrm{~h}$ and $72 \mathrm{~h}$ (Figure 4A and 4B). Statistics confirmed that PLAGL1 transcript level of tumor cells was significantly lower than that of non-tumor cells $(p<0.05)$ (Figure 4A). This study also showed that PLAGL1 mRNA levels in SkHep1 and Huh7 were insignificant (expression value $=0.00$ ) respect to fibroblasts (Figure 4A). On the contrary, the levels of PPARy transcripts were in general higher in HCC cells than in fibroblasts during proliferation. Moreover, this gene transcription was exceedingly higher in Huh7 cells than in the other tumor cell-lines (Figure 4C).

qPCR data was also utilized to perform a detailed analysis of the dynamic of PLAGL1, p53 and PPARy genes transcription in each cell line during proliferation. In fibroblasts, PLAGL1 mRNA level decreased after the release from serum starvation until $\mathrm{T}=48 \mathrm{~h}$ and then gradually increased until the end of the experiment $(\mathrm{T}=96 \mathrm{~h})$ (Figure 5A). Among the tumor cell-lines, only SKHep1 cells exhibited a transcriptional profile similar to that of fibroblasts, i.e., a significant reduction of the PLAGL1 mRNA level until $\mathrm{T}=72 \mathrm{~h}$ and then increased to levels statistically not different to that obtained at $\mathrm{T}=0 \mathrm{~h}$ (Figure 5C). Whereas PLC/PRF/5, HepG2 and Huh7 cells did not show variations in the transcript levels of PLAGL1 gene along the growth curves (Figure 5B, 5D and 5E).

The PLAGL1 protein interacts, among others, with p53 for controlling cell proliferation [13]. Therefore, we wondered whether transcription of the genes encoding these two proteins would keep any relationship with each other. As mentioned before, we found that p53 mRNA level in fibroblasts decreased from $\mathrm{T}=0 \mathrm{~h}$ until $\mathrm{T}=48 \mathrm{~h}$ during the proliferation assay, and then gradually increased until $\mathrm{T}=96 \mathrm{~h}$, following a similar transcription pattern of PLAGL1 in this cell type (Figure 5A). Tumor cells presented different dynamics of this gene transcription along the proliferation curve. In PLC/PRF/5 cells $p 53$ gene transcript level decreased significantly after the release from serum starvation and remained at low levels during the proliferation assay (Figure 5B). In SkHep1 and HepG 2 cells $p 53$ transcription remained without changes during the proliferation experiment (Figure 5C and 5D). Huh7 cells, on the contrary, exhibited a significant, and sustained, increase in the level of p53 gene transcription respect to the mRNA level that this cell type had at $\mathrm{T}=0 \mathrm{~h}$ of the experiment (Figure 5E).

Considering that PLAGL1 acts also as a transcription factor of the PPARy gene, RT-qPCR was performed to determine the transcript level of this gene during cell proliferation. This analysis revealed that in all cell lines the transcript level of PPARy decreased respect to the level at $\mathrm{T}=0 \mathrm{~h}$, and it remained low during the proliferation experiment (Figure 5).

\section{PLAGL1, p53 and p21 proteins expression}

The expression levels of PLAGL1, p53 and p21 proteins were determined in all cell-lines by Western blot analysis. We compared the data of PLAGL1, p53 and p21 protein levels for each tumor cell-line with those obtained for fibroblasts at the same time point of the proliferation curve. Despite high variability in PLAGL1 expression was seen, the statistical analysis demonstrated that there were not significant differences in the expression level of PLAGL1 between tumor cells and fibroblasts (Figure 6A). Regarding to $\mathrm{p} 53$ protein, the comparisons showed that the expression level of this protein was significantly lower in tumor cell lines than in fibroblasts, except for Huh7

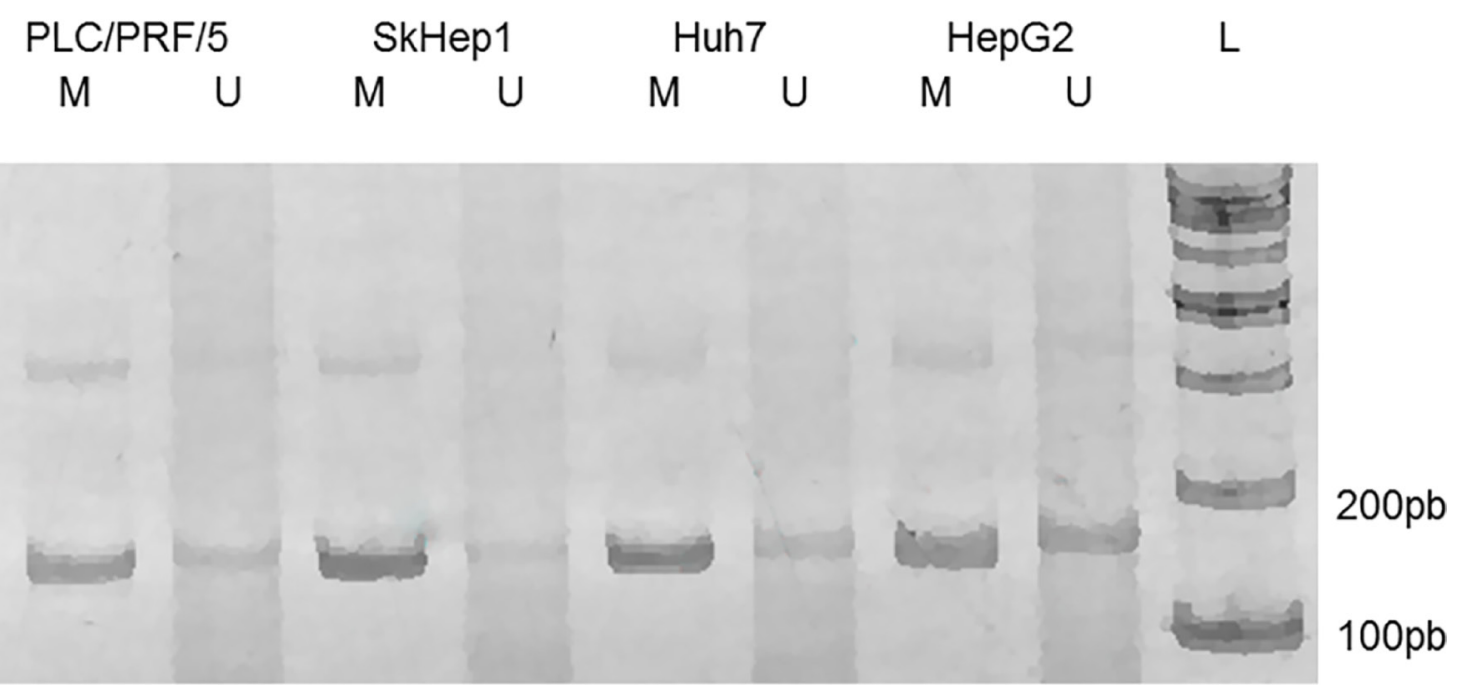

Figure 2: MS-PCR of the genomic region corresponding to the P1 promoter of PLAGL1 gene. Gel electrophoresis of the PCR products showed that the methylated DNA-fraction is larger than the unmethylated. L, size marker; M, methylated; U, unmethylated. 
cells after $48 \mathrm{~h}$ and $72 \mathrm{~h}$ in culture (Figure 6B). Similar analysis of the data obtained for $\mathrm{p} 21$ protein revealed that its expression level was significantly higher in fibroblasts than in tumor cell lines along the experiment (Figure 6C). The data was also analyzed for each cell-line individually. In fibroblasts, PLAGL1 and p53 protein levels did not experiment demonstrable changes during cell growth, except for PLAGL1 protein that exhibited a significant increase just at the end of the proliferation curve $(\mathrm{T}=96 \mathrm{~h}$ ) (Figure 7A). This is in clear contrast with the dynamics of PLAGL1 and p53 genes transcription, which

A

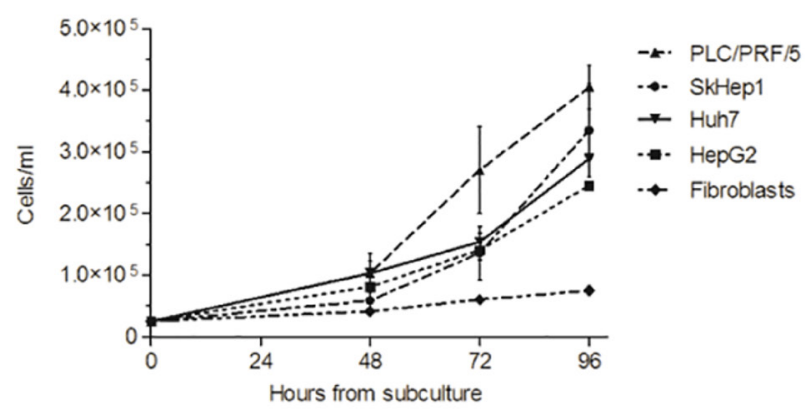

C

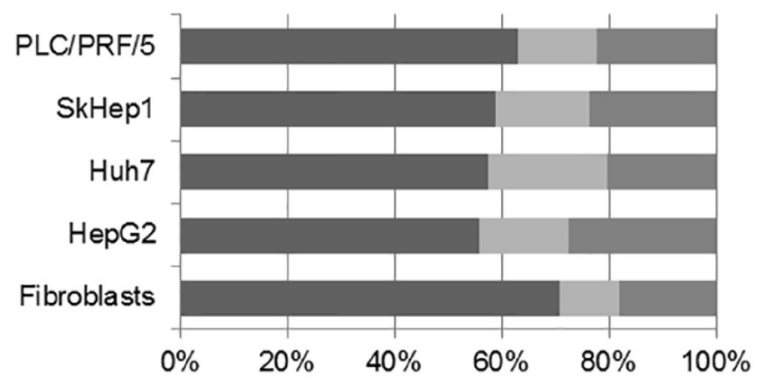

E

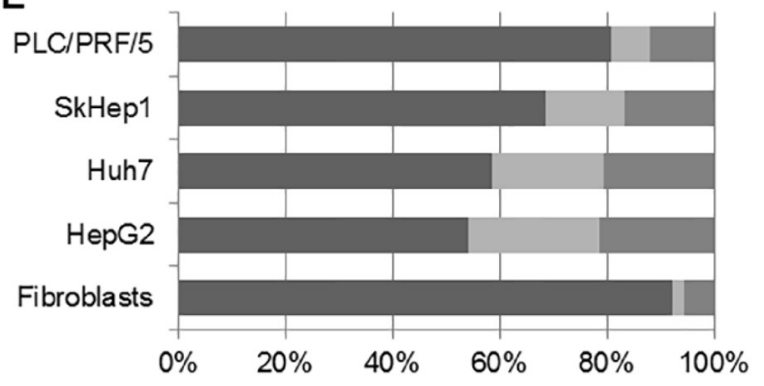

experimented a significant reduction in their transcripts level after serum starvation and then increasing until $\mathrm{T}=96 \mathrm{~h}$ (Figure 5A). The expression of $\mathrm{p} 21$ protein exhibited a different profile; statistically significant increases were detected at each time-point during fibroblasts proliferation (Figure 7A).

The tumor cell-lines showed a rather uniform expression level of PLAGL1 during the growth assays, except for SkHep1 cells that presented significant lower expression levels at 48 and $96 \mathrm{~h}$ of the experiment (Figure 7). As to the expression of p53 and p21 proteins,

B

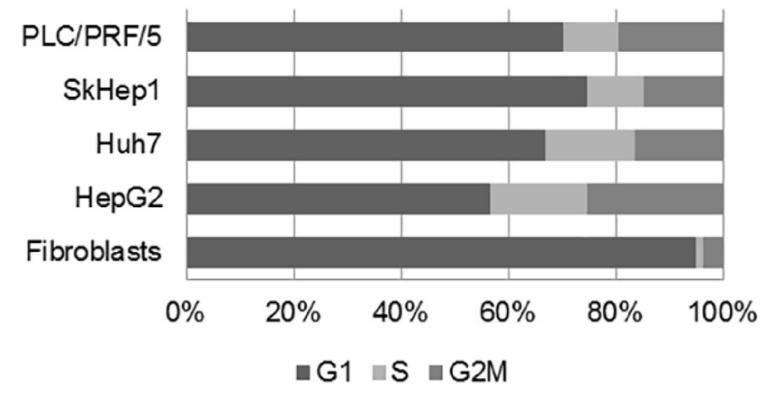

D
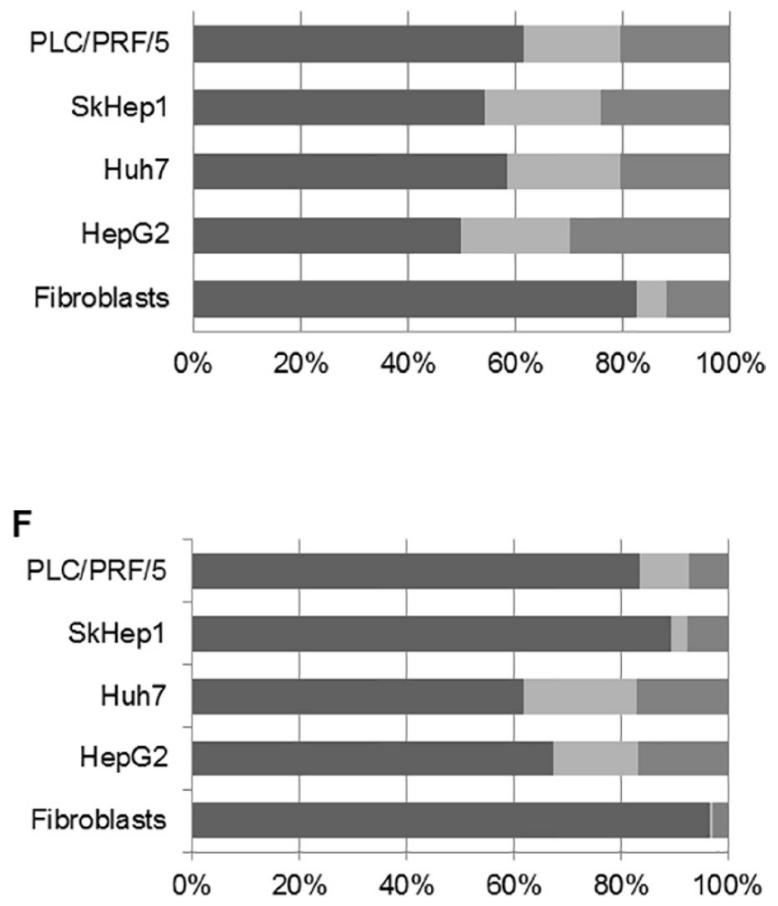

Figure 3: HepG2, Huh7, SkHep1 and PLC/PRF/5 cells proliferate faster than non-tumoral fibroblasts. (A) Aliquots of $25 \times 10^{3}$ cells $/ \mathrm{ml}$ were seeded in 4 flasks and cultured in $10 \mathrm{ml}$ of DMEM medium containing 10\% FBS for 24, 48, 72 and $96 \mathrm{~h}$. At each time point, the cells were harvested, and their number counted in a Neubauer chamber. Fibroblasts have a constant growth during the experiment and reached $7.5 \times 10^{4}$ cells $/ \mathrm{ml}$ at $96 \mathrm{~h}$, in contrast to the $2.5-4.5 \times 10^{5}$ cells $/ \mathrm{ml}$ reached by $\mathrm{HCC}$ cells at the same time point. (B-F) Show the percentage of cells in each phase of the cell cycle at $0 \mathrm{~h}, 24 \mathrm{~h}, 48 \mathrm{~h}, 72 \mathrm{~h}$ and $96 \mathrm{~h}$, respectively. 

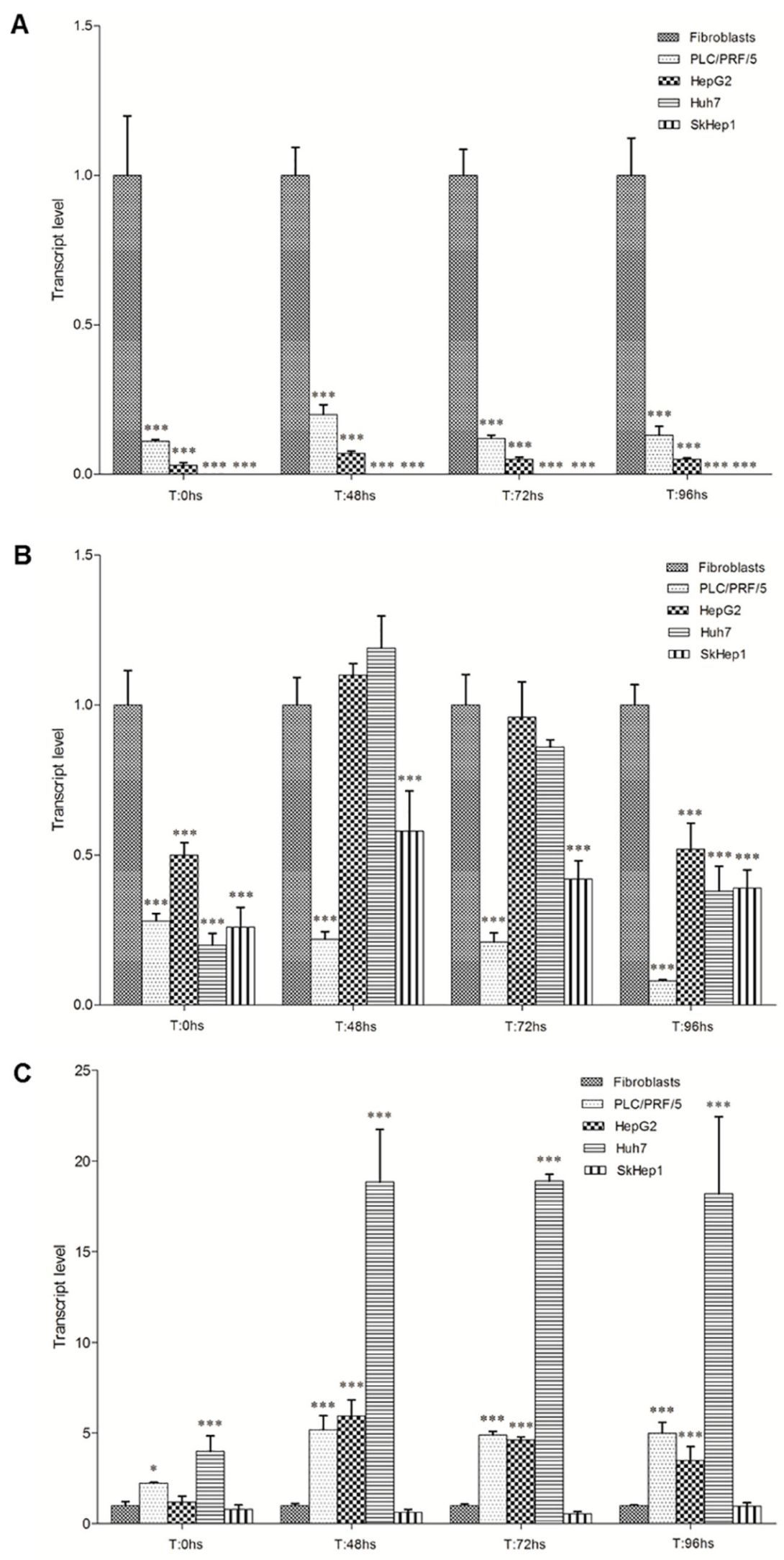

Figure 4: Transcript level of PLAGL1, p53 and PPARy during proliferation. The mRNA level of each tumor cell-line was compared with that of fibroblasts at the same time point of the proliferation curve. (A) PLAGL1. (B) p53. (C) PPARy. Bars represent mean \pm SD. Asterisks indicate that the mRNA levels compared are significantly different; ${ }^{*} p<0.05,{ }^{* *} p<0.001,{ }^{* * * *} p<0.0001$. 
we found different profiles among tumor cell-lines. In $\mathrm{PLC} / \mathrm{PRF} / 5$ cells, these proteins levels experimented a reduction respect the values obtained at $0 \mathrm{~h}$, but only the reduction of p53 expression reach statistically significant levels during proliferation (Figure 7B). In SkHep1 cells, p53 expression increased at $72 \mathrm{~h}$ and decreased at $96 \mathrm{~h}$, while p21 expression doubled the level during proliferation (Figure 7C). The HepG2 cell-line presented similar levels of p53 protein expression in all the time-points of the proliferation curve, whereas p21 protein underwent a conspicuous increase of expression at $48 \mathrm{~h}$ and then returned to similar levels of that of the synchronized cells (Figure 7D). Finally, in Huh7 cells p53 protein expression level did not change along the experiment, and the p21 protein was not detected by Western blot (Figure 7E).

\section{PLAGL1 and p21 proteins expression in situ}

The expression in situ of PLAGL1 and p21 proteins was determined by immunocytochemistry in the four hepatoma cell-lines and fibroblasts. PLAGL1 immunoreactivity was weakly detected in the cytoplasm of tumor cells, while in normal fibroblasts its expression was readily observed in the nucleus and the cytoplasm. As regard to p21 protein, nuclear immunoreactivity was detected in normal fibroblasts and in HepG2 and SkHep1 cells. While PLC/PRF/5 cells presented weak immunoreaction only in the cytoplasm, and it was not detected in Huh7 (Figure 8).

PLAGL1 and p21 proteins expression in situ was also assessed in ten tissue samples from patients with hepatic tumors by immunohistochemistry. The microscopic analysis revealed that, except for two (H004 and H011), all tumor samples had lower expression of PLAGL1 protein than normal liver cells (Figure 9; Table 2). Moreover, we observed that the protein localized only in the cytoplasms of tumor cells, and that in one tumor (H011) the protein formed aggregated close to the nuclear membrane (Figure 9). As to the p21 protein expression, the microscopic exam revealed that in six out of the 11 samples the protein was not detected, and the remaining had lower level of p21 expression than non-tumoral cells (Table 2).

\section{PLAGL1 protein overexpression}

To study the effect of PLAGL1 overexpression on $\mathrm{HCC}$ cells proliferation, we performed transfection assays in two tumor cell-lines (PLC/PRF/5 and HepG2) with a plasmid encoding the full-length protein. Despite of the low efficiency of the transfection method (about $10 \%$ in both cell types), the PLAGL1 protein level increased significantly in cell transfected with prk7PLAGL1, respect to non-transfected cells (Figures 10
A

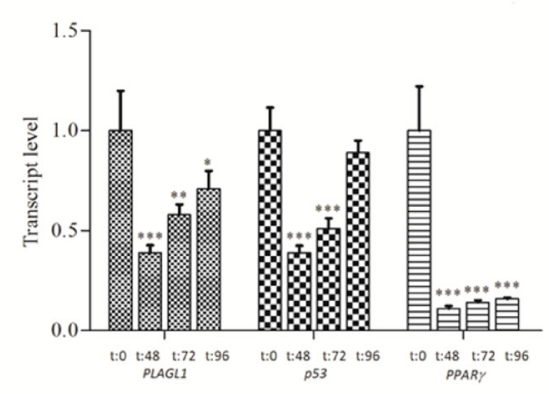

B

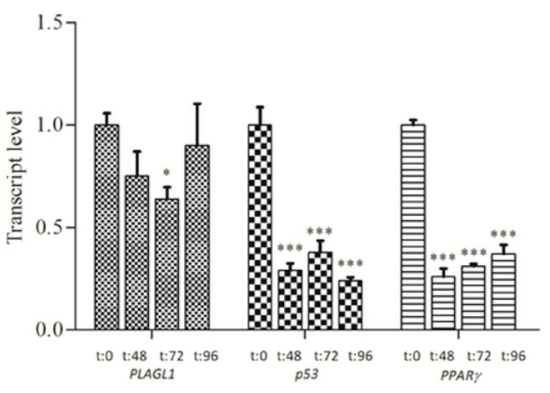

C

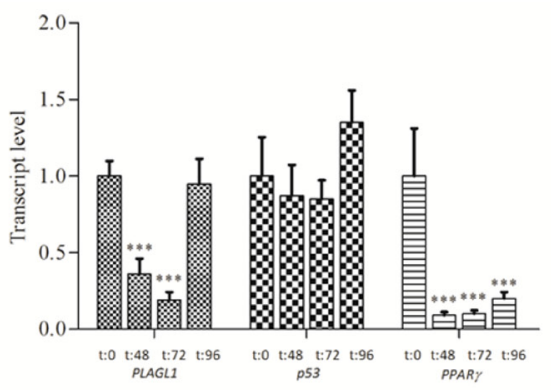

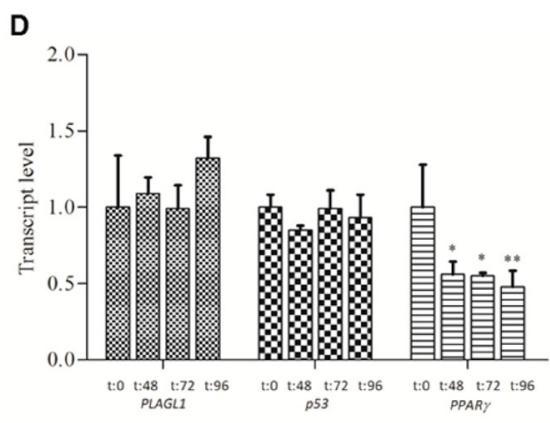

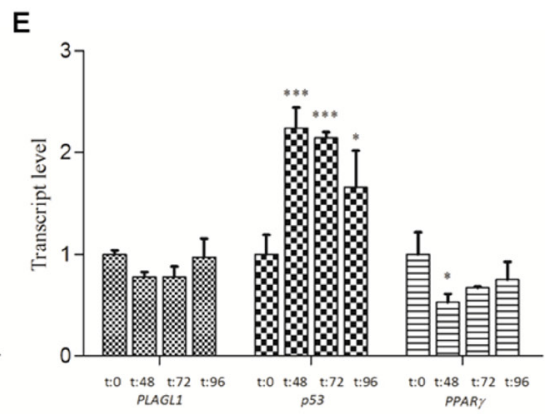

Figure 5: PLAGL1, p53 and PPARy transcript level during in vitro cell growth. (A) Fibroblasts. (B) PLC/PRF/5. (C) SkHep1. (D) HepG2. (E) Huh7. The statistical comparisons were made between any given time point and $\mathrm{T}=0 \mathrm{~h}$ for each cell line individually. Bars represent mean $\pm \mathrm{SD}$. Asterisks indicate that the difference is significant; ${ }^{*} p<0.05,{ }^{* *} p<0.001,{ }^{* * *} p<0.0001$. 
A

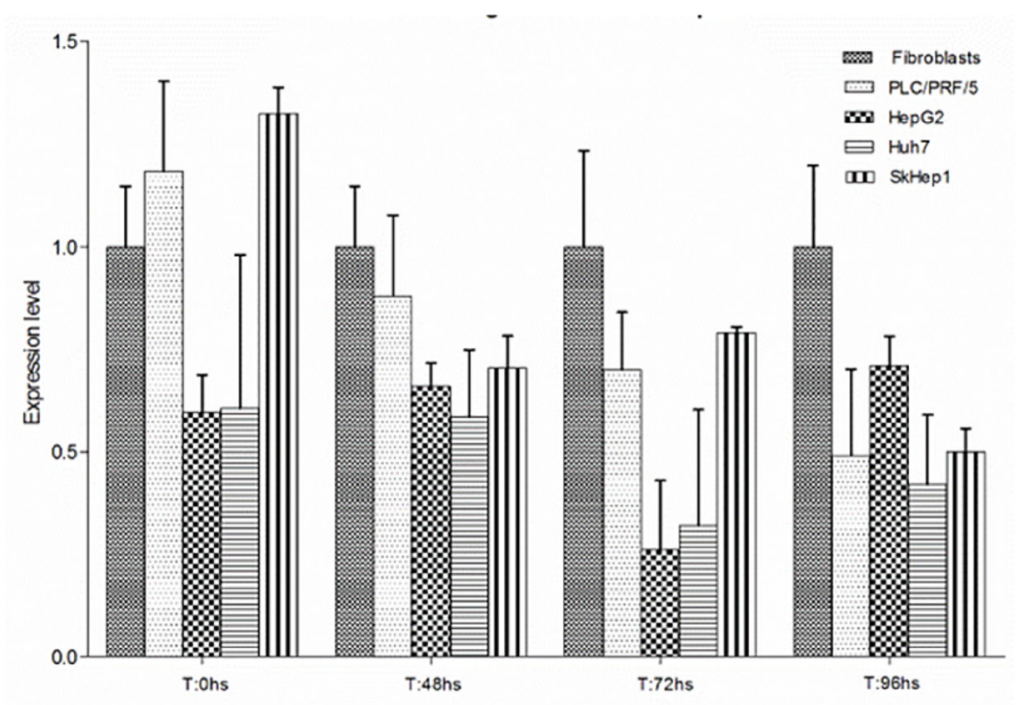

B

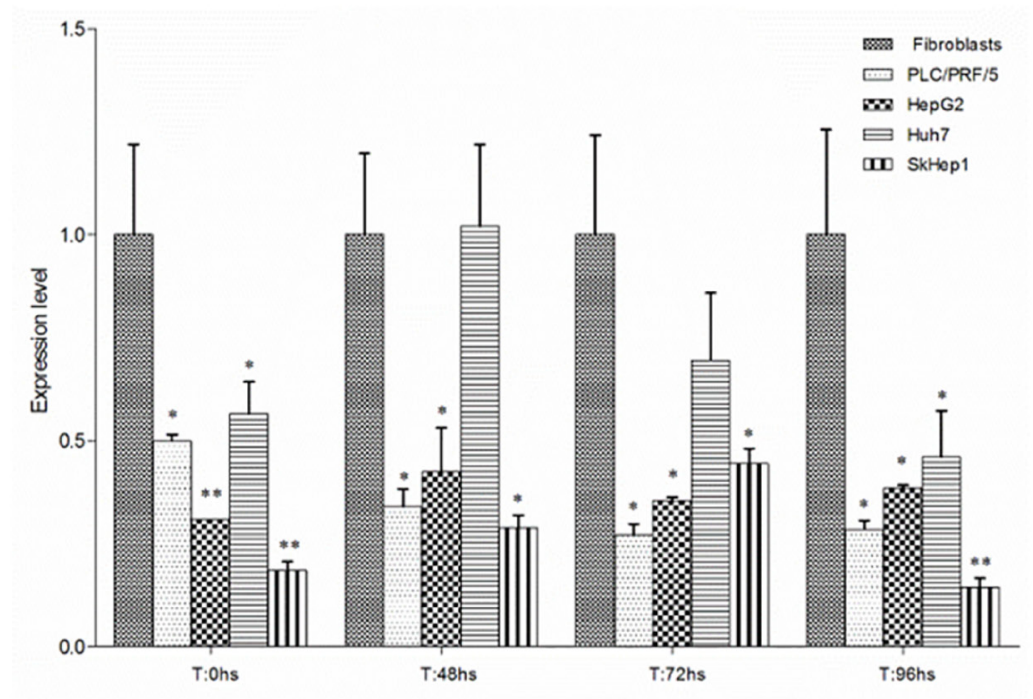

C

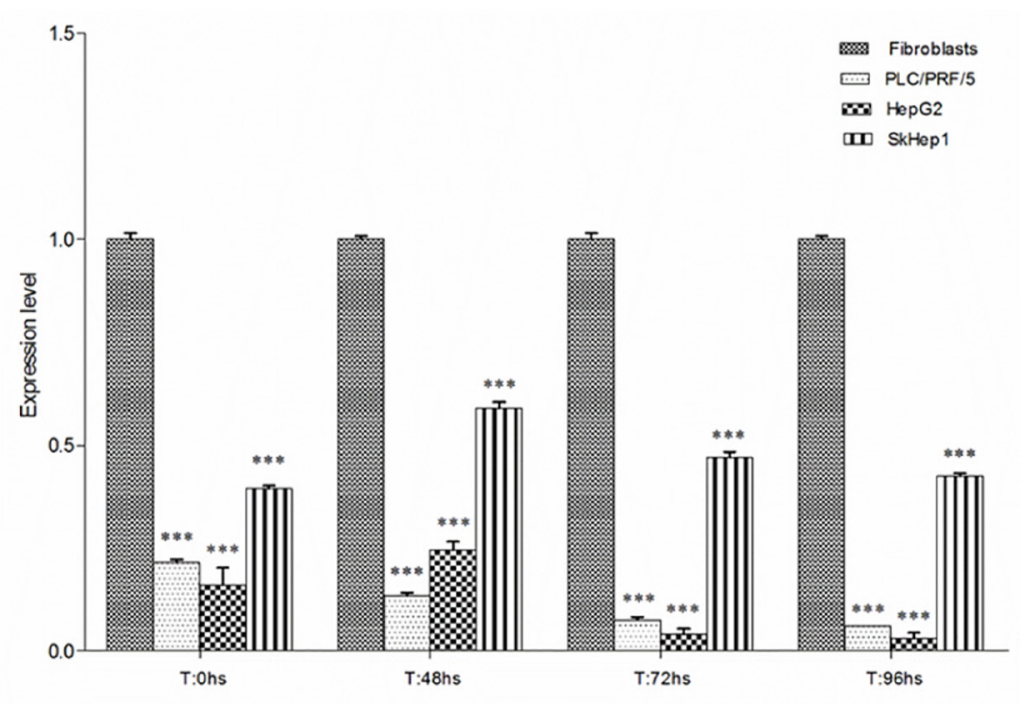

Figure 6: Proteins expression in normal and tumor cells during proliferation. PLAGL1 (A), p53 (B) and p21 (C) proteins levels were determined, and compared with that of fibroblasts at each time point. Bars represent mean $\pm \mathrm{SD}$. Asterisks indicate statistically significant differences; ${ }^{*} p<0.05,{ }^{* *} p<0.001,{ }^{* * *} p<0.0001$. 
A
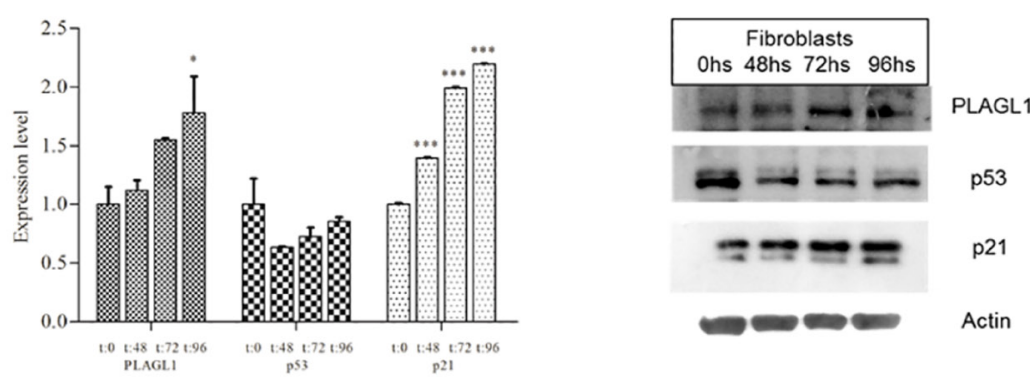

B
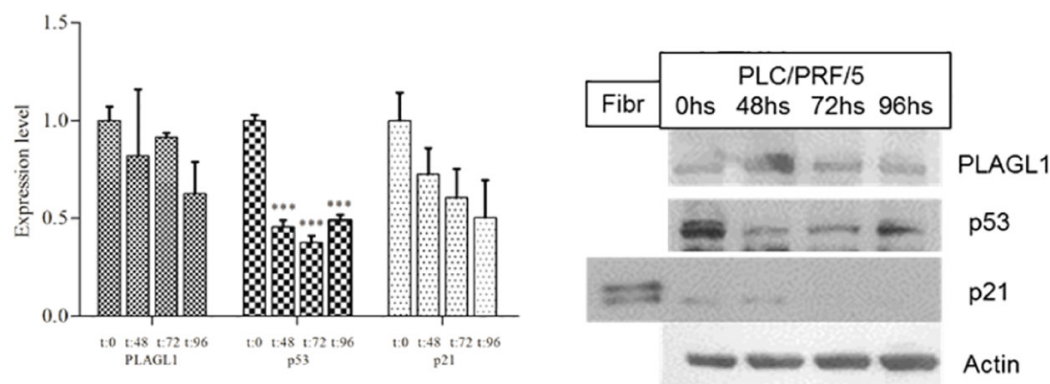

C
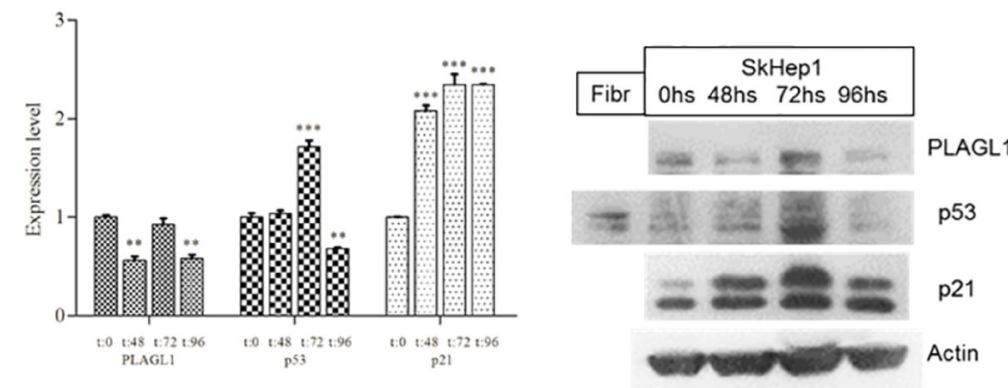

D
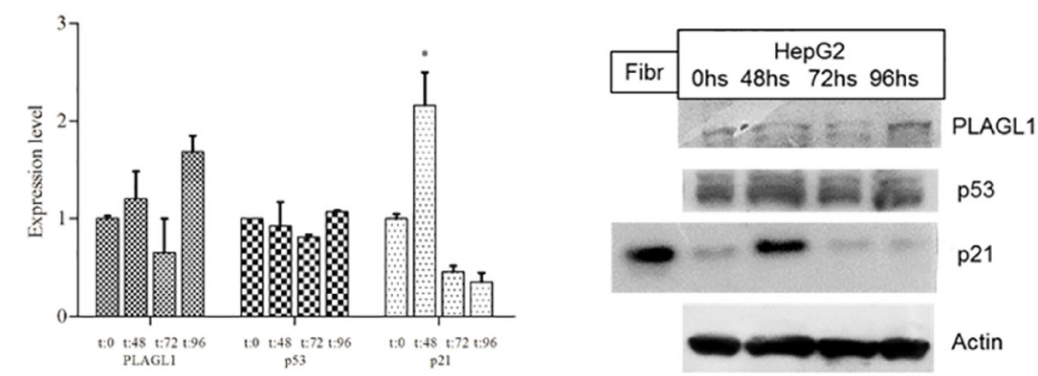

E
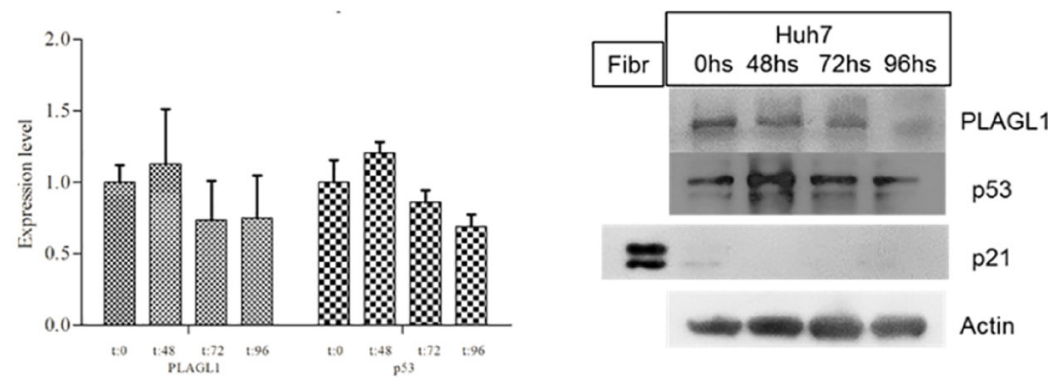

Figure 7: Expressiont level of PLAGL1, p53 and p21 of each cell line during proliferation. The Western blot data corresponding to each time point was compared with that of T $=0$ h. (A) Fibroblasts. (B) PLC/PRF/5. (C) SkHep1. (D) HepG2. (E) Huh7. A protein extract from fibroblasts (Fibr) was used as a signal control for the antibody p21. Representative blots are shown at the side of each graph. Actin was used as loading control. Bars represent mean \pm SD. Asterisks indicate statistically significant differences; ${ }^{*} p<0.05$, ${ }^{* *} p<0.001,{ }^{* * *} p<0.0001$ 
and 11). However, Western blot analyses performed to determine the p21 protein level revealed that it increased, in response to PLAGL1 overexpression, only in HepG2 cells (Figures 11B, 11C), which harbour a wild type p53 gene. Simultaneously we investigated whether this overexpression of PLAGL1 protein affects proliferation of tumor cells, by determining the number of cells for each experimental condition after 30 hs post-transfection. We found that $\mathrm{PLC} / \mathrm{PRF} / 5$ cells without transfection proliferated actively from $2.2 \times 10^{5} \mathrm{cell} / \mathrm{ml}$ at $\mathrm{T}=0 \mathrm{hs}$ to $4.2 \times 10^{5} \mathrm{cell} / \mathrm{ml}$ at $\mathrm{T}=30 \mathrm{hs}$, while cells transfected with prk7-PLAGL1 reached $3.2 \times 10^{5}$ cell $/ \mathrm{ml}$ at $\mathrm{T}=30 \mathrm{hs}$. As mentioned before, HepG2 cells were the least proliferative, and this was confirmed with this experiment. Transfection of these cells with the prk7-PLAGL1 construct almost arrested cell growth $\left(1.70 \times 10^{5} \mathrm{cell} / \mathrm{ml}\right.$ at $\mathrm{T}=0 \mathrm{hs}$ vs $1.75 \times 10^{5} \mathrm{cell} / \mathrm{ml}$ at $\left.\mathrm{T}=30 \mathrm{hs}\right)$, compared with untransfected cells $\left(2.5 \times 10^{5} \mathrm{cell} / \mathrm{ml}\right.$ at $\left.\mathrm{T}=0 \mathrm{hs}\right)$.

\section{DISCUSSION}

PLAGL1 is a TSG involved in the pathogenesis of several tumor types, including ovarian, gastric, pituitary and colorectal cancer $[20,24,25,30,31]$. Considering that $\mathrm{LOH}$ at the PLAGL1 locus and hypermethylation of its $\mathrm{P} 1$ promoter occur more frequently than gene mutations, the mechanisms by which this gene participates in the tumorigenic process seem to be different from those of typical TSGs. In fact, punctual mutations of the PLAGL1 gene were detected in only $71(0.3 \%)$ out of 21,029 tumor samples of all kind registered in the Catalog of Somatic Mutations in Cancer (COSMIC; http://cancer.sanger. ac.uk/cosmic). To add more complexity, it has been also reported that overexpression of PLAGL1 was detected in some human neoplasms such as glioma and clear cell renal cell carcinoma, suggesting an oncogenic function, as well [28, 29]. As regard to $\mathrm{HCC}$, Midorikawa et al.
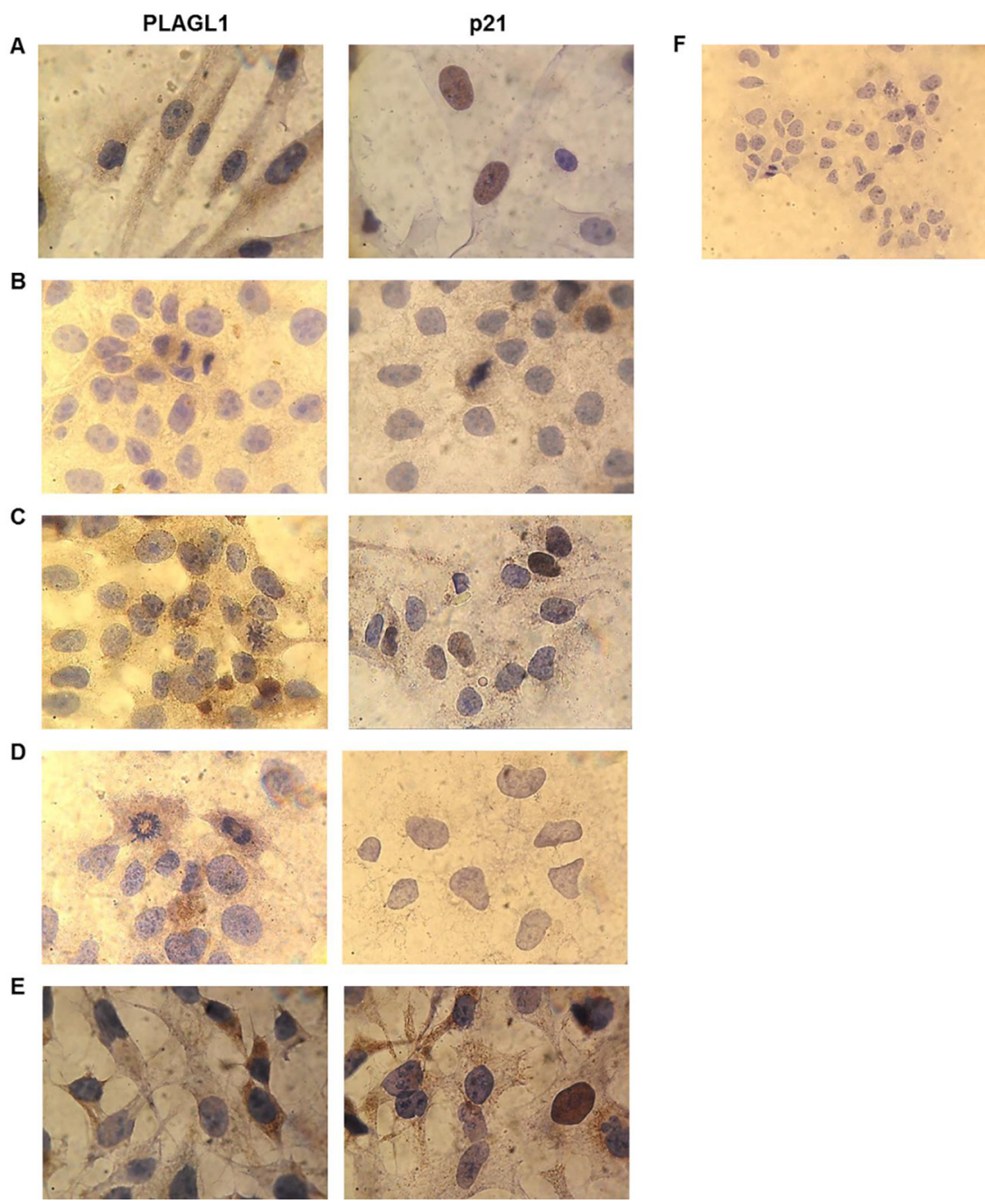

Figure 8: Immunocytochemistry for PLAGL1 and p21 proteins in tumor and normal cells. Microscopic exam of the preparations revealed that PLAGL1 protein localized only in the cytoplasm of tumor cells, while p21 exhibited both nuclear and cytoplasmatic localization. Similar to Western blot analysis, this protein was not detected in Huh7 cells. (A) Fibroblasts; (B) PLC/PRF/5; (C) HepG2; (D) Huh7; (E) SkHep1; (F) Negative control. Magnification 1000× (A-E) and 400× (F). 

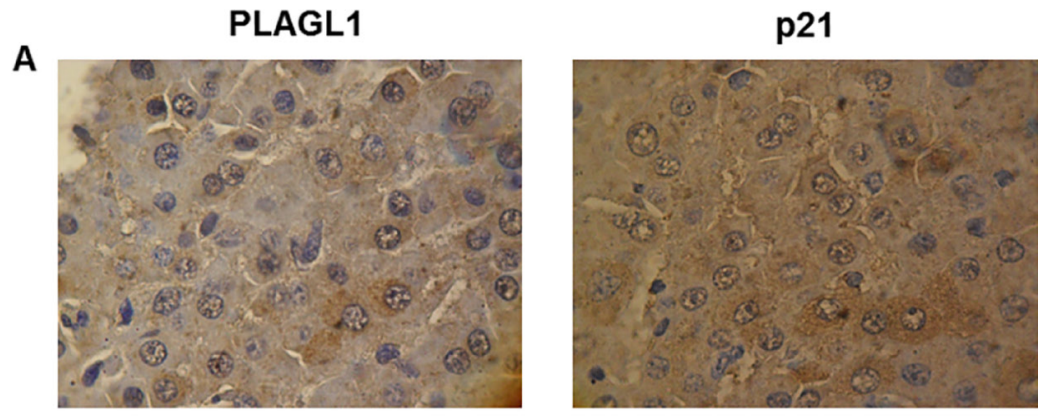

B
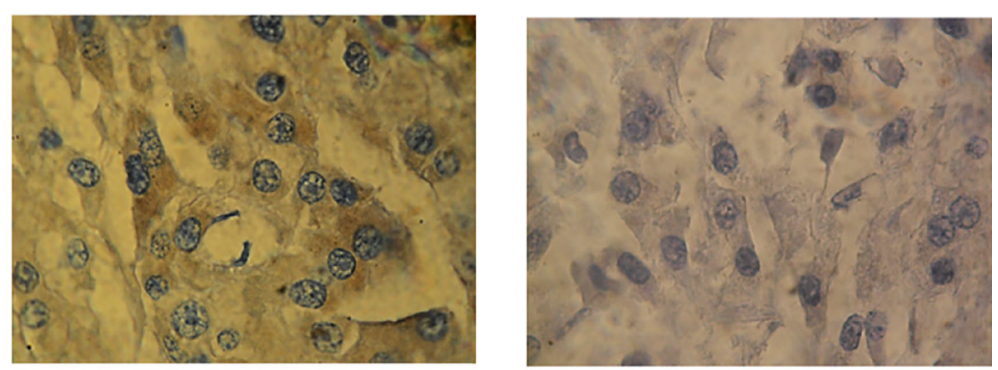

C
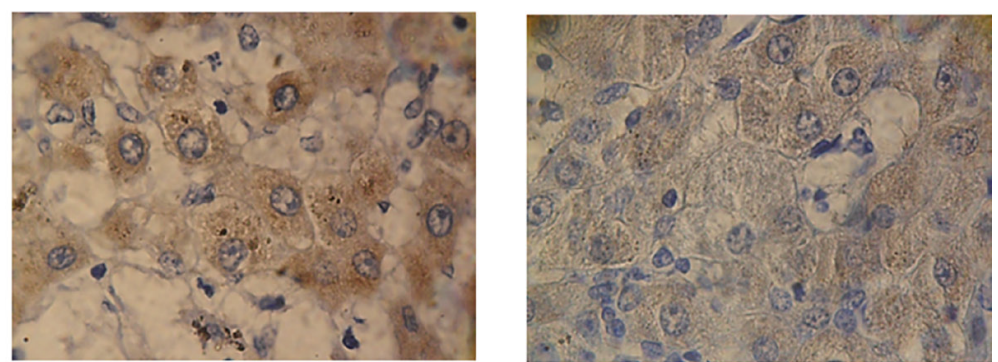

D
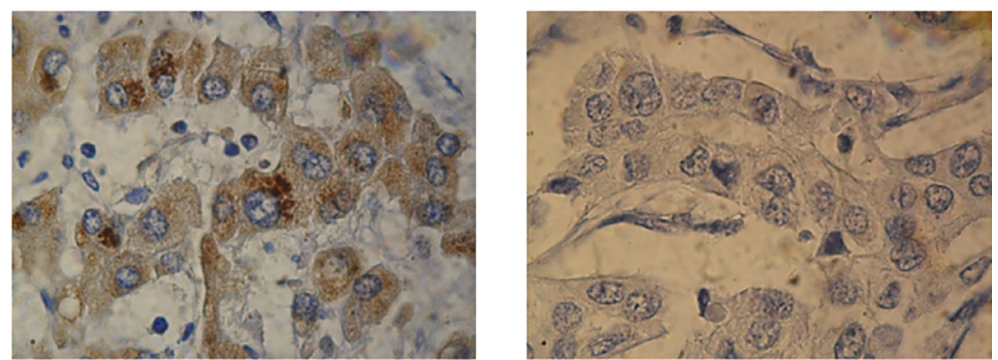

$\mathrm{E}$

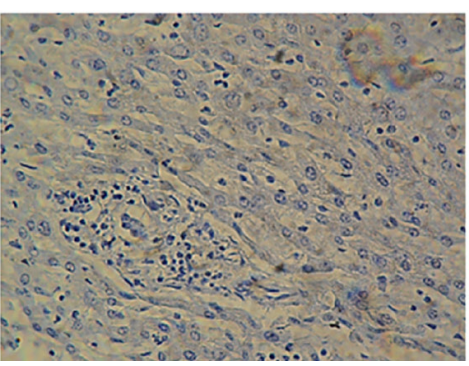

Figure 9: Immunohistochemical analyses of PLAGL1 and p21 proteins expression in liver tumors. Representative photomicrograph of non-tumoral liver tissue stained with anti-PLAGL1 and anti-p21 antibodies (A). (B) H003. (C) H012. (D) H011. (E) Negative control. Weak or moderate expression of PLAGL1 and p21 proteins was observed in tumor samples compared to normal liver tissue. Note that both proteins were detected in the cytoplasm and nuclei of non-tumor liver, while PLAGL1 localized only in the cytoplasms of tumor cells. Magnification 1000× (A-D) and 400× (E). 
found that $\mathrm{LOH}$ at the chromosome region 6q24, hypermethylation of PLAGL1 promoter at the remaining allele and low mRNA levels were frequent in tissue samples from patients with hepatoma [26]. Therefore, we wondered how genomic imbalances at the chromosome region 6q24, where PLAGL1 gene maps, would affect the transcription and expression level of this gene, and ultimately how this influences the proliferative capacity of liver cancer cells. To this aim, we investigated the profile of $6 q 24$ aberrations of the hepatoma cell lines HepG2, Huh7, PLC/PRF/5 and SkHep1. The aCGH analysis showed that Huh7 and SkHep1 cells present losses of genetic material at 6q24.2, HepG2 exhibited gains, and $\mathrm{PLC} / \mathrm{PRF} / 5$ has no abnormalities in this region (Figure 1 and Table 1). Also three out of seven liver tumors we analyzed had losses of genetic material from this region. This data may suggest that abnormalities at this chromosome region are common in $\mathrm{HCC}$, however it should be kept in mind that other regions, such as $1 \mathrm{p}$, $8 \mathrm{p}$ and $17 \mathrm{p}$, are affected by imbalances more frequently $[26,32]$. Moreover, these changes are not specific of this tumor type, losses at chromosome $6 \mathrm{q}$ have also been found, among others, in pheochromocytomas and gastric adenocarcinomas $[31,33]$. We also determined that the regulator region of $P L A G L 1$ ( $\mathrm{P} 1$ promoter) is heavily methylated in the four hepatoma cell lines (Figure 2), and most likely this explain the low mRNA level of the PLAGL1 gene in these tumor cell lines (Figure 4A). Reduced transcription, due to hypermethylation of P1 promoter of this gene, was already demonstrated in gastric adenocarcinomas and HCC [26, 31]. However, the relationship between genomic imbalances, the methylation status of the P1 promoter and the transcription level of this gene is apparently not direct. In fact, the tumor cellline HepG2 presents gain of genomic material at $6 \mathrm{q} 24$ (Figure 1), the lowest degree of P1 promoter methylation (Figure 2), and still the transcript and expression level of PLAGL1 is similarly low to that of the other hepatoma cell lines (Figure 4A and Figure 6A).

The proliferation assays we performed by cellcounting demonstrated that the HCC cells grow much faster than the normal fibroblasts used as control. Accordingly, flow cytometry analysis showed that during the entire assay, the four tumor cell lines always presented higher percentage of cells in the G2/M phase than non-tumoral fibroblasts. This results were somehow expected, since cell cycle deregulation, which results in unscheduled proliferation, is a common feature of human cancer. In this context we determined the mRNA and protein levels of PLAGL1, and the RT-qPCR analysis
A

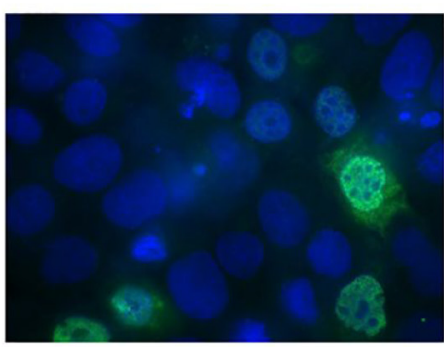

B
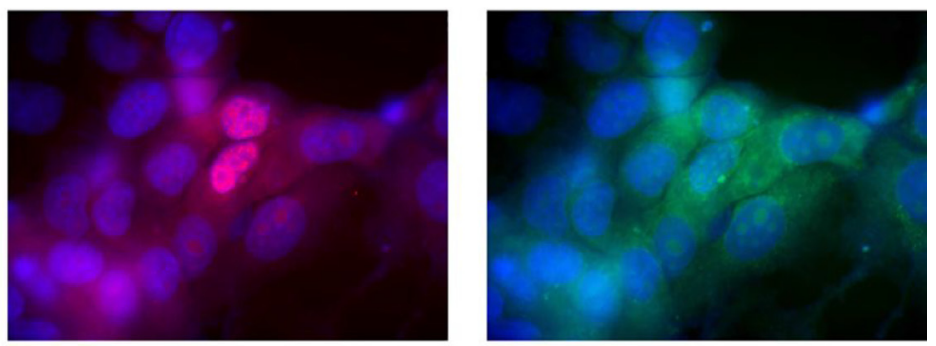

D
C

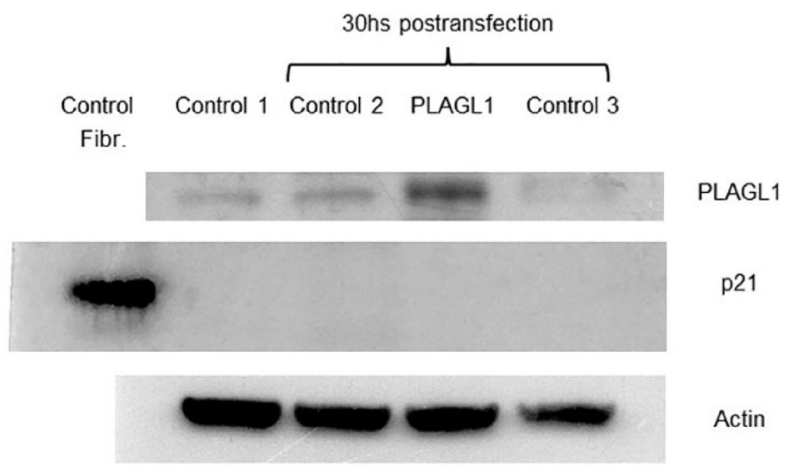

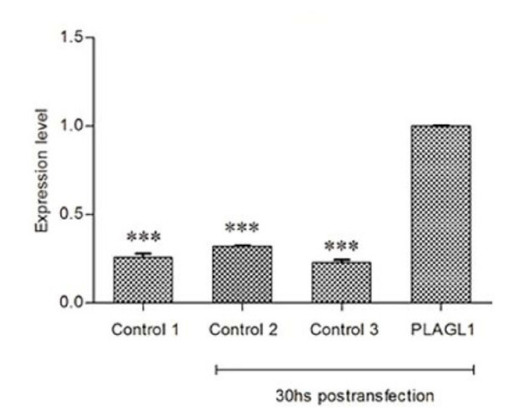

Figure 10: Overexpression of PLAGL1 protein in PLC/PRF/5 cells. (A) Immunofluorescence of transfected cells with an antibody anti-PLAGL1(Green). (B) Immunofluorescence of transfected cells with antibodies against PLAGL1 (Red) and p21 (Green). (C) Representative blots of PLAGL1 and p21 proteins. A protein extract from fibroblasts (Fibr.) was used as a signal control for the antibody against p21. Actin was used as loading control. (D) PLAGL1 relative expression: Control 1 = T: 0 hs; Control $2=$ No plasmid; Control $3=$ Empty plasmid; PLAGL1 $=\mathrm{PLC} / \mathrm{PRF} / 5$ cells transfected with the plasmid prk7-PLAGL1. Bars represent mean $\pm \mathrm{SD}$. Asterisks indicate statistically significant differences $\left({ }^{* * *} p<0.0001\right)$. 
revealed that transcription of PLAGL1 in tumoral cells is significantly lower than in normal fibroblasts, but no significant differences in terms of protein expression were detected between tumor cell-lines and normal fibroblasts. As mentioned before, reduced transcription of PLAGL1 is common to several tumor types $[24,25,31]$, but the results of protein expression are intriguing. It is well accepted that the abundance of proteins may or may not keep a direct relationship with the mRNA levels because of the differences in the mechanisms regulating transcription and translation, and also that mRNAs are produced at a much lower rate, and are less stable than proteins [34], inclusive specific PLAGL1-targeting miRNAs (miR-98; miR-15a/16; miR-23a/b), leading to mRNA degradation, have been identified $[35,36]$. Also it has to be taken into consideration the cellular organization of PLAGL1 gene transcription. Royo et al. demonstrated that PLAGL1 mRNA accumulates juxtaposed to the nucleolus in normal fibroblasts, and that it is released from this nuclear compartment, increasing the synthesis of PLAGL1 protein, in response to stimuli that induce cell cycle arrest [37]. Thus the silmilar protein level between these two cell types is perhaps the result of less pronounced nucleolar retention of PLAGL1 transcripts in tumor cells than in normal fibroblasts. An alternative explanation may be that Western blot data is not appropriated for comparing the abundance of the PLAGL1 protein between different cell types, despite the growth conditions were identical. This seems to be supported by our findings from immunocytochemistry analyses, which indeed showed differences in terms of in situ expression of PLAGL1 protein in tumor cells (lower) compared to normal fibroblast (Figures 8 and 9), suggesting that the level of PLAGL1 protein needed to control the proliferation of normal cells is different from that for tumor cells. Immunocytochemistry also revealed that the signal was only present in the cytoplasm of hepatoma cells, and this is in clear conflict with its nuclear functions as a transcription factor and cofactor of other proteins [38]. Alterations in the nuclear localization signal (NLS) domain of the protein may not be responsible for this cellular localization of PLAGL1, since mutations of this gene are uncommon in tumors (COSMIC; http:// cancer.sanger.ac.uk/cosmic). Instead, it is tempting to speculate that the defect may be due to abnormalities in
A

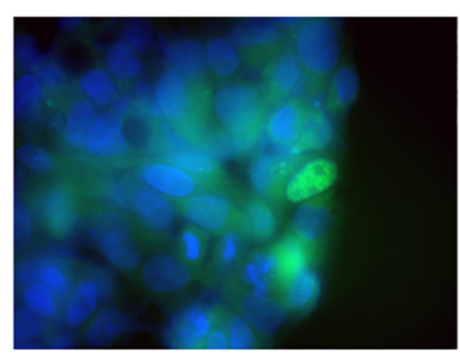

B

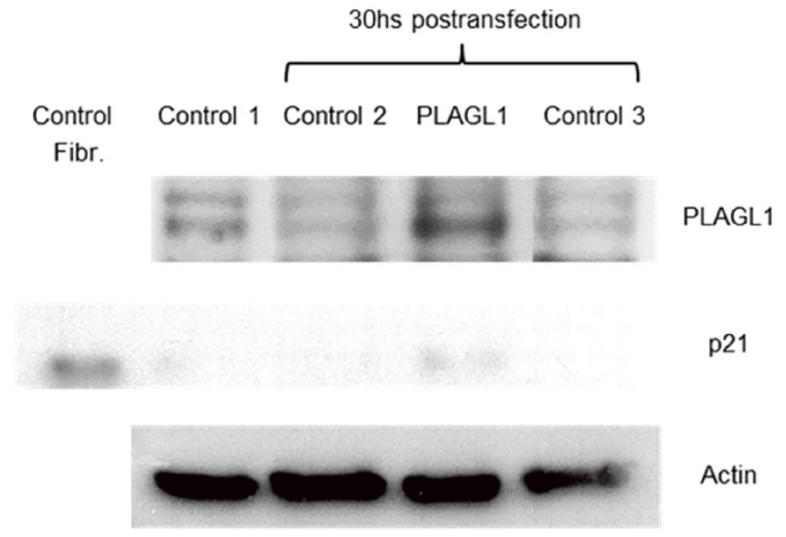

C

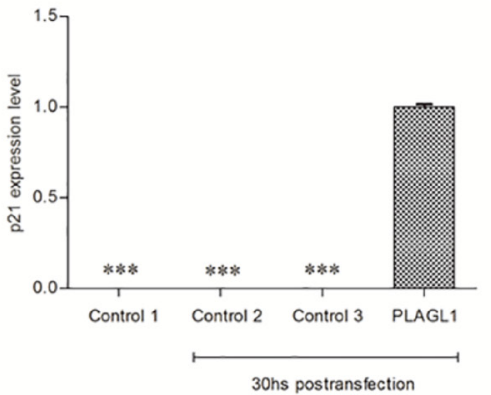

Figure 11: Overexpression of PLAGL1 protein in HepG2 cells. (A) Immunofluorescence of transfected cells with antibody antiPLAGL1 (green). (B) Representative blots of PLAGL1 and p21 proteins. A protein extract from fibroblasts (Fibr.) was used as a signal control for the antibody p21. Actin was used as loading control. (C) PLAGL1 and p21 relative expression: Control $1=\mathrm{T}$ : 0 hs; Control 2 = No plasmid; Control 3 = Empty plasmid; PLAGL1 = HepG2 cells transfected with the plasmid prk7-PLAGL1. Bars represent mean \pm SD. Asterisks indicate statistically significant differences $\left({ }^{* * *} p<0.0001\right)$. 
other players of the cellular trafficking, such us Importin $\alpha 1$ (KPNA2) or Exportin1 (XPO1) [38, 39].

As mentioned before, PLAGL1 interacts with $\mathrm{p} 53$, and then the complex induces the expression of the $p 21$ gene, which is essential for controlling proliferation through cell cycle arrest $[14,16]$. Therefore, we also profiled the genomic regions where these genes map. aCGH revealed that, except for SkHep1, the tumor cell lines do not harbour quantitative imbalances in the $p 53$ region (Table 1). PLAGL1 and p53 protein expression usually remained uniform during tumor-cells proliferation (Figure 7), but almost always at lower levels in HCC cells than normal fibroblasts. RT-qPCR studies demonstrated that $p 53$ transcription is also rather constant during $\mathrm{HCC}$ cells proliferation, and this is in clear contrast with the dynamic transcription observed in normal fibroblasts (Figure 5). This cell-type exhibited the highest level of p53 mRNA at T: $0 \mathrm{~h}$, which decreased to a minimum at $48 \mathrm{~h}$ in culture and then increased again until the end of the experiment (T:96 h), similar to the transcription profile showed by PLAGL1 gene (Figure 5A), and it was accompanied by a reduction of the percentage of cells in G2/M phase conforming cell-cycle regulation takes place. Huang et al. demonstrated the interaction between PLAGL1 and p53 proteins, and proposed that both proteins participate together in the control of normal growth [14]. While Rozenfeld-Granot et al. reported that p53 acts as a transcription factor of PLAGL1 gene [40]. Now our study provides evidence for an apparent orchestrated transcription process of both genes during normal cells proliferation, which gets disturbed in HCC cells. The increase in the transcriptional activity may serve for maintaining constant the level of protein needed for cell-cycle regulation. Supportive evidence comes from our PLAGL1 overexpression studies. Transfection assays in PLC/PRF/5 and HepG2 cell-lines, with a construct that encodes the full-length protein, demonstrated that PLAGL1 level increased in cell transfected with prk7PLAGL1, respect to non-transfected cells (Figures 10 and 11), and that the level of p21 protein increased only in HepG2, the cell-system with functional $p 53$ gene. In spite of the fact that statistics showed that the differences were not significant, the data from cell count indicates that cell-growth lessened in both cell-types. Obviously, caution is warranted when interpreting these findings, but them suggest that abrogation of PLAGL1 function plays a role in HCC cells proliferation, like in other tumor types [20, 25, 31]. Moreover, one has to accommodate the fact that that PLC/PRF/5 cells with non-functional p53 also underwent growth retardation, which indicates that PLAGL1 anti-proliferative activity is performed through additional mechanisms to those involving p53 and p21 proteins. In fact, Varrault et al. have recently shown that PLAGL1 target genes include numerous genes involved in extracellular matrix composition, cell adhesion and cell signalling [41].
The genomic study revealed that the region $6 \mathrm{p} 21.3$, where $p 21$ maps, showed gains of genetic material in SkHep1and HepG2, and losses in Huh7 (Table 1). Earlier studies performed by Koga et al. demonstrated, like us, that Huh7 cells have not detectable p21 expression (Figure 7E) [42], and most probably these results are consequence of the chromosome alteration in this cell line. The gain of genomic material in SkHep1 and HepG resulted in higher expression level of p21 in these cell-lines respect to $\mathrm{PLC} / \mathrm{PRF} / 5$ cells, which does not harbour changes at 6p21.3 (Figure 1 and Table 1). However, statistical comparisons demonstrated that it is always lower than that of normal fibroblasts. This is in agreement with the data of immunocytochemistry analyses, which showed that the protein is hardly detected in the cytoplasm of tumor cells (Figure 8). The data of reduced expression of p21 during proliferation in HCC cell lines respect to non-tumoral cells, coinciding with low $p 53$ mRNA and protein level, fit well with the antiproliferative function of these proteins [43-46]. However, dysregulation of the balance between proliferation and cell death cannot be explained only by a decrease in the expression level of a few proteins. Instead, the signalling pathways established during HCC cells growth are more complex, and our study shows that PLAGL1 plays an important role.

PLAGL1 also induces the transcription of the PPARy gene [47], and by its protein could inhibit cellular proliferation through $\mathrm{p} 21$ regulation $[17,48]$. Therefore, we studied the transcriptional activity of the PPARy gene during cell proliferation. We found that after releasing cells from serum starvation, its mRNA level decreased respect to that found at $\mathrm{T}=0$ hs (Figure 5). Interestingly, only SkHep 1 cells exhibited genomic losses at the region where PPARy maps, and consequently had the lowest level of PPARy transcripts respect to the other tumor celllines (Table 1 and Figure 4C). This notwithstanding, the reduction of the transcript level is most likely related to its function as suppressor of cell division and survival [49-51]. However, some gene activity seems to be needed to maintain cell-adherence during proliferation, since it was demonstrated in HCC cells that treatment with PPARy inhibitors or gene silencing with small interfering RNAs cause cell detachment and anoikis [52, 53]. In this context, the low, but steady levels of PLAGL1 protein during HCC cells proliferation could also be associated with maintaining this necessary PPARy gene activity.

\section{MATERIALS AND METHODS}

\section{Cell lines culture and tissue samples}

The human hepatoma cell lines HepG2, Huh7, $\mathrm{PLC} / \mathrm{PRF} / 5$ and SkHep1 derived from patients with HCC were acquired from American Type Culture Collection. Considering that the PLAGL1 expression level in fibroblasts and hepatocytes, are similar (http://genecards.org), 
normal fibroblasts at low passages established in our laboratory, were used as control. Cells were cultured in Dulbecco's Modified Eagle's Medium/Nutrient Mixture F-12 Ham (DMEM) (Sigma-Aldrich) containing 1\% penicillin/streptomycin and 10\% fetal bovine serum (FBS) (Invitrogen) at $37^{\circ} \mathrm{C}$, constant humidity and $5 \% \mathrm{CO}_{2}$. All experiments were performed with cells at low passages.

Seven samples from patients with $\mathrm{HCC}$, one with Cholangiocellular Carcinoma (CCC), two with Hepatoadenocarcinoma (HAC) and one with Focal Nodular Hyperplasia (FNH) were collected at the Italian Hospital of Buenos Aires in accordance with the ethical standards approved by the institutional Ethical Committee and the informed written consent of the patients. Liver tissue from patients without cancer was used as control. The samples were preserved at $-70^{\circ} \mathrm{C}$ until their use.

\section{Quantitative genomic aberrations by Array- CGH analysis}

DNA extraction was performed using a commercial kit, according to the manufacturer's instructions (Qiagen). DNA from healthy individuals (Promega), was used as reference for the hybridization assays. Array-CGH $(\mathrm{aCGH})$ analyses were performed as previously described by Royo et al. [54].

\section{Methyl specific PCR (MS-PCR)}

Genomic DNA from each tumor cell line (500ng), was subjected to bisulfite treatment, which converts unmethylated cytosines to uracils and leaves methylated cytosines unchanged, using the EZ DNA MehtylationDirect kit (Zymo). Specific sets of primers for MS$\mathrm{PCR}$, designed to amplify a region of the $\mathrm{P} 1$ promoter containing a methylated or unmethylated $\mathrm{CpG}$ island, were published by Leal et al. [55]. The PCR reaction contained $200 \mu \mathrm{mol} / \mathrm{L}$ of dNTPs, $200 \mu \mathrm{mol} / \mathrm{L}$ of $\mathrm{MgCl}_{2}, 100 \mathrm{ng}$ of DNA, $200 \mathrm{pmol} / \mathrm{L}$ of primers and $0.5 \mu 1$ of GoTaq in a final volume of $25 \mu \mathrm{l}$. While the PCR conditions were as follow: initial denaturing at $94^{\circ} \mathrm{C}$ for $3 \mathrm{~min}, 35$ cycles at $94^{\circ} \mathrm{C}$ for $30 \mathrm{sec}, 51^{\circ} \mathrm{C}$ for $45 \mathrm{sec}$ and $72^{\circ} \mathrm{C}$ for $30 \mathrm{sec}$, and a final extension for $5 \mathrm{~min}$ at $72^{\circ} \mathrm{C}$. The PCR products were separated in a $10 \%$ polyacrylamide gel, stained with SYBR Green $(0.0001 \%$ solution in loading buffer), and images were acquired in a gel documentation system equipped with a CCD camera.

\section{Proliferation assays and flow cytometry}

Each cell line was plated onto $75 \mathrm{~cm}^{2}$ flasks in DMEM medium containing 10\% FBS, and cultured until reaching $80 \%$ confluence, and then the cells were incubated in DMEM medium containing 3\% FBS for $24 \mathrm{~h}$. After this period of cell synchronization, four flasks for each cell line were seeded with aliquots of $25 \times 10^{3} \mathrm{cell} / \mathrm{s} / \mathrm{ml}$ and cultured in DMEM medium containing 10\% FBS for 24, 48, 72 and $96 \mathrm{~h}$, respectively. At each time point, the cells were harvested, aliquots were stained with trypan blue, and the number of viable cells determined in a Neubauer chamber. The doubling time (DT) and the constant rate of each cell line was determined using the exponential growth function $\left(\mathrm{Y}=\mathrm{Y}_{0}^{*} \exp \left(\mathrm{k}^{*} \mathrm{X}\right)\right)$.

For cytometry analysis, an aliquot of cells from each time point of the proliferation curve was washed in PBS $1 \mathrm{X}$ and fixed in $1 \mathrm{ml}$ of ethanol $70 \%$ (ice-cold) for $30 \mathrm{~min}$. Then, the cells were washed twice by centrifugation at $4000 \mathrm{rpm}$ for $10 \mathrm{~min}$ at $4^{\circ} \mathrm{C}$ in PBS $1 \mathrm{X}$. After centrifugation, the pellet was directly treated with a RNAse solution $(100 \mu \mathrm{g} / \mathrm{ml})$, and stained by adding $400 \mu \mathrm{l}$ of propidium iodide $(2 \mu \mathrm{g} / \mathrm{ml})$ per million cells during $15 \mathrm{~min}$. The samples were then examined in a BD FACS Canto flow cytometer and the data analysis was performed with the FlowJo 10 computer program. All samples were analysed in duplicate of two biological replicates.

\section{Quantitative RT-PCR}

Aliquots of the cells collected at each time point of the proliferation curve were used for RNA extraction by the TRIzol method (Invitrogen), according to the protocol provided by the manufacturer. RNA concentration was measured in a Nanophotometer TM P-Class (IMPLEN). Reverse transcription of $1 \mu \mathrm{g}$ of RNA to cDNA was performed using a commercial kit (Invitrogen) in a thermal cycler (Eppendorf). The conditions were as follow: incubation at $65^{\circ} \mathrm{C}$ for $5 \mathrm{~min}$, followed by incubation at $37^{\circ} \mathrm{C}$ for $52 \mathrm{~min}$ and at $72^{\circ} \mathrm{C}$ for $15 \mathrm{~min}$.

To study the transcript level of the PLAGL1, p53 and PPARy genes, aliquots of $70 \mathrm{ng}$ of cDNA, $10 \mu \mathrm{l}$ of the MixSso (BIO-RAD), $1 \mu 1$ of the Probe + Primer 20X and $2 \mu 1$ of $\mathrm{H}_{2} \mathrm{O}$ were used for each reaction in an Opticon2 instrument. The optimum quantity of cDNA (70 ng) for the detection of the transcripts and the efficiency of the technique was determined by the performance of the standard curve. To determine the efficiency of the technique, the slope of the line was calculated from the calibration assay of the standard curve of each transcript. This efficiency $(\approx 90 \%)$ was obtained through the application of the formula: $\mathrm{E}=10^{(-1 / \text { slope })}-1$. The conditions of the PCR were as follow: incubation at $96^{\circ} \mathrm{C}$ for 2 min; followed by 50 cycles at $96^{\circ} \mathrm{C}$ for $15 \mathrm{sec}, 60^{\circ} \mathrm{C}$ for $1 \mathrm{~min}$ and $72^{\circ} \mathrm{C}$ for $1 \mathrm{~min}$. Primers of PLAGL1 (Assay $\mathrm{N}^{\circ}$ H00414677_m1), p53 (Assay $\mathrm{N}^{\circ} \mathrm{H} 01034249$ m1), PPARy (Assay $\mathrm{N}^{\circ} \mathrm{H} 01115513 \mathrm{~m} 1$ ) and PPIA, the reference gene, (Assay Reagents Human PPIA P.N. 4333763F), were synthesized by Life Technologies. All samples were analysed in triplicate from two biological replicates. The analysis of the data was performed using the DNA Engine Opticon2 software (Gene Expression Analysis for iCycleriQ Real Time PCR detection System - BIO- 
RAD). For each gene, in each sample, a value of threshold cycle $(\mathrm{Ct})$ was obtained, established as the number of cycles in which the reaction reaches the value of 0.02 of fluorescence intensity. This value of $\mathrm{Ct}$ corresponds to the average of the three values obtained in the technical replicates. The transcript level of PLAGL1, p53, PPARy and PPIA was quantified using the $2^{-\Delta \Delta \mathrm{Ct}} \operatorname{method}(\Delta \Delta \mathrm{Ct}=$ $\left.\left[\mathrm{Ct}_{\text {Target gene }}-\mathrm{Ct}_{P P I A}\right]_{\text {experiment }}-\left[\mathrm{Ct}_{\text {Target gene }}-\mathrm{Ct}_{P P I A}\right]_{\text {control }}\right)$.

\section{Western blot}

Aliquots of cells from each time point of the proliferation curve were washed by centrifugation in PBS $1 \mathrm{X}$, treated with lysis buffer containing $50 \mathrm{mM}$ of Heppes, $150 \mathrm{mM}$ of $\mathrm{NaCl}, 0.5 \mathrm{mM}$ of EDTA, $1 \%$ of Nonidet P-40 and $10 \mu \mathrm{l}$ of protease inhibitors/ $1 \mathrm{ml}$ of buffer (100X, Thermo Scientific) for $30 \mathrm{~min}$ and centrifuged at 12000 rpm for $30 \mathrm{~min}$ at $4^{\circ} \mathrm{C}$. The concentration of proteins in the total lysate was determined by the Bradford protein assay. The Bradford reagent consists of 1 volume of $0.02 \%$ Coomassie Brilliant Blue (G-250) dissolved in ethanol, 2 volumes of H3PO4 and 17 volumes of distilled water. The calibration curve for this assay was prepared with serial dilutions of bovine serum albumin. The solution for each measurement contained $10 \mu \mathrm{l}$ of total lysate, $10 \mu \mathrm{l}$ of distilled water and $200 \mu \mathrm{l}$ of Bradford reagent. Once the protein concentration was determined, aliquots of $10 \mu \mathrm{g}$ of total lysate were mixed with loading buffer, heated at $95^{\circ} \mathrm{C}$ for $5 \mathrm{~min}$, and then loaded onto $10 \% \mathrm{SDS}$-polyacrylamide gel and separated at $100 \mathrm{~V}$ during $90 \mathrm{~min}$. Then, the proteins were transferred onto $0.45 \mu \mathrm{m}$ nitrocellulose membrane, blocked in 5\% milk overnight at $4^{\circ} \mathrm{C}$ and then incubated 2 hours with primary antibody antiPLAGL1 (1:500, sc-22811, Santa Cruz Biotechnology), anti-p53 (1:500, sc-1311, Santa Cruz Biotechnology) and anti-p21 (1:500, sc-397, Santa Cruz Biotechnology). After hybridization with primary antibody, the membrane was washed with Tris-buffered saline containing Tween-20 three times, then incubated with horseradish peroxidaselabeled secondary antibody (Santa Cruz Biotechnology) for 1 hour at room temperature and washed with Trisbuffered saline containing Tween-20 three times. Final detection was performed with ECL Chemiluminescent Western blotting reagents (Thermo Fisher Scientific). An antibody against Actin (1:500, sc-1615, Santa Cruz Biotechnology) was used for gel-loading control. Western blot signals were quantified using ImageJ program. The intensity of each band was normalized respect to that of actin (loading control) at the same time point. The assay was performed from two biological replicates.

\section{PLAGL1 expression in situ}

To study the expression level of PLAGL1 and p21 proteins in situ, we performed immunofluorescence, immunocytochemistry and immunohystochemistry.
The cell-lines were grown directly onto glass coverslips under the same conditions used for the other assays and harvested simultaneously with the cells used for qRTPCR and Western blot. The coverslips were washed in PBS $1 \mathrm{X}$, and the cells fixed in paraformaldehyde $(2 \%$ in PBS $1 \mathrm{X}$ ) at $4^{\circ} \mathrm{C}$ for $15 \mathrm{~min}$. Endogenous peroxidase activity was quenched by the incubation of the slides in $4 \%$ hydrogen peroxide solution in PBS $1 \mathrm{X}$ for $40 \mathrm{~min}$. The slides were washed in PBS $1 \mathrm{X}$ and incubated for $1 \mathrm{~h}$ in $3 \%$ bovine serum albumin to block unspecific sites, and then incubated with a 1:100 dilution of antihuman PLAGL1 and anti-human p21 overnight at $4^{\circ} \mathrm{C}$. The detection was performed with a 1:200 dilution of secondary antibody conjugated to HRP for $1 \mathrm{~h}$ at room temperature. Then, slides were washed in PBS $1 \mathrm{X}$ and developed in 3,3'-diaminobenzidine (Liquid DAB + Substrate Chromogen System, Cell Marque). Cells were counterstained in Mayer's hematoxylin, washed in PBS $1 \mathrm{X}$, dehydrated in an ethanol series, cleared in xylene, and mounted with a solvent-based mounting medium (ALUN Metraquímica). All cell lines were stained in duplicates, and negative controls were prepared by excluding the primary antibodies in the procedure.

For immunofluorescence, the coveslips were treated similarly but excluding the incubation in hydrogen peroxide, using secondary antibodies conjugated to Alexa Fluor 546 (red) and Alexa Fluor 488 (green) and mounted with Vectashield-DAPI ${ }^{\circledR}$.

PLAGL1 immunoreactivity was also analysed in 11 tissue-samples from patients with hepatic tumors, as well as non-tumoral liver tissue. Immunohistochemistry was performed on $4 \mu \mathrm{m}$ thick paraffin sections that were deparaffinized and rehydrated in an ethanol series. Antigen retrieval was carried out by microwaving for $15 \mathrm{~min}$ in citrate buffer, pH 6.0 (10 mM citric acid, $10 \mathrm{mM}$ sodium citrate), cooled and washed twice in PBS $1 \mathrm{X}$ for $5 \mathrm{~min}$. The histological preparations were permeabilized with $0.05 \%$ Triton in PBS $1 \mathrm{X}$, washed once in PBS $1 \mathrm{X}$ and next incubated in $4 \%$ hydrogen peroxide solution in PBS $1 \mathrm{X}$ for $40 \mathrm{~min}$. Then, the same antibodies treatment and detection procedure were used as described before. The immunostained sections were evaluated using a Olympus light microscope. Protein immunostaining intensity was scored as: strong $(+++)$, moderate $(++)$, weak $(+)$ and negative $(-)$.

\section{PLAGL1 protein overexpression}

To study the effect of PLAGL1 overexpression on $\mathrm{HCC}$ cells proliferation, we performed transfection assays in the PLC/PRF/5 and HepG2 cell lines with the plasmid prk7-PLAGL1 (kindly provided by Dr Laurent Journot, Institut de Genomique Fonctionnelle, Universite de Montpellier, France) [56]. These cell lines were chosen because HepG2 is normal as regard to p53 gene, while $\mathrm{PLC} / \mathrm{PRF} / 5$ presents a mutation in this gene (R249S) that encodes for a non-functional p53 protein. Aliquots 
of $5 \times 10^{4}$ cells were cultured onto 6 -well plates in complete DMEM medium for $72 \mathrm{~h}$. At this time point (T $=0 \mathrm{hs} ; 70 \%$ confluence), the cells were transfected with the plasmid prk7-PLAGL1, using Lipofectamine 2000 (Invitrogen) following the manufacturer's protocol. After a transfection period (6 hs) without sera, the medium was replaced by DMEM containing 10\% FBS and incubated for 30 aditional hs. Controls included non-transfected cells harvested at $\mathrm{T}=0 \mathrm{hs}$ and $\mathrm{T}=30 \mathrm{hs}$, as well as cells transfected with the empty vector plasmid.

The cells from each experimental condition were harvested, aliquots were stained with trypan blue, and the number of viable cells determined in a Neubauer chamber. PLAGL1 and p21 proteins levels were determined by Western blot and inmunfluorescence following the protocol described above. The experiments were carried out in duplicate.

\section{Statistics}

All statistical analysis and graph were performed with Graph Pad Prism v.5.0. Comparisons between samples were evaluated with analysis of variance (ANOVA). Diferences between results were considered significant if the $p$-value was $<0.05\left({ }^{*}\right) ;<0.001\left({ }^{* *}\right)$ and $<0.0001\left(^{* * *}\right)$.

\section{Author contributions}

AFVB \& LAP designed the study; AFVB, CNS, FLl \& FR performed the experiments; FR, AFVB, PZ, RV \& JLZ did the bioinformatic and statistic analyses; AFVB wrote the first draft; LAP wrote the manuscript. All authors read and approved the final manuscript.

\section{CONFLICTS OF INTEREST} interest.

Authors declares that they have no conflicts of

\section{FUNDING}

This study was funded by the National Council of Sciences and Technologies (CONICET); Argentine Agency for Science and Technology. Grant ANPCyT FONCyT, PICT-2011-1897 to Luis A. Parada and by the Department of Economic Development and Infrastructure, Basque Gouverment, Spain, ELKARTEK KK-2017/00084 to José L. Zugaza. The funders had no role in the preparation of the manuscript and the decision to publish.

\section{REFERENCES}

1. El-Serag HB, Rudolph KL. Hepatocellular carcinoma: epidemiology and molecular carcinogenesis.
Gastroenterology. 2007; 132:2557-76. https://doi. org/10.1053/j.gastro.2007.04.061.

2. Mittal S, El-Serag HB. Epidemiology of hepatocellular carcinoma: consider the population. J Clin Gastroenterol. 2013; 47:S2-6. https://doi.org/10.1097/ MCG.0b013e3182872f29.

3. Knudsen ES, Gopal P, Singal AG. The changing landscape of hepatocellular carcinoma: etiology, genetics, and therapy. Am J Pathol. 2014; 184:574-83. https://doi.org/10.1016/j. ajpath.2013.10.028.

4. Buendia MA, Neuveut C. Hepatocellular carcinoma. Cold Spring Harb Perspect Med. 2015; 5:a021444. https://doi. org/10.1101/cshperspect.a021444.

5. Sia D, Villanueva A. Signaling pathways in hepatocellular carcinoma. Oncology. 2011; 81:18-23. https://doi. org/10.1159/000333254.

6. Iakova P, Timchenko L, Timchenko NA. Intracellular signaling and hepatocellular carcinoma. Semin Cancer Biol. 2011; 21:28-34. https://doi.org/10.1016/j.semcancer.2010.09.001.

7. Zhivotovsky B, Orrenius S. Cell cycle and cell death in disease: past, present and future. J Intern Med. 2010; 268:395409. https://doi.org/10.1111/j.1365-2796.2010.02282.x.

8. Schulze K, Nault JC, Villanueva A. Genetic profiling of hepatocellular carcinoma using next-generation sequencing. J Hepatol. 2016; 65:1031-42. https://doi.org/10.1016/j. jhep.2016.05.035.

9. Zheng L, Liang P, Li J, Huang XB, Liu SC, Zhao HZ, Han KQ, Wang Z. ShRNA-Targeted COMMD7 Suppresses Hepatocellular Carcinoma Growth. PLoS One. 2012; $7: \mathrm{e} 45412$.

10. Sun H, Hou H, Lu P, Zhang L, Zhao F, Ge C, Wang T, Yao M, Li J. Isocorydine inhibits cell proliferation in hepatocellular carcinoma cell lines by inducing $\mathrm{G} 2 / \mathrm{m}$ cell cycle arrest and apoptosis. PLoS One. 2012; 7:e36808.

11. Li W, Huang X, Tong H, Wang Y, Zhang T, Wang W, Dai L, Li T, Lin S, Wu H. Comparison of the regulation of betacatenin signaling by type I, type II and type III interferons in hepatocellular carcinoma cells. PLoS One. 2012; 7:e47040.

12. Varrault A, Ciani E, Apiou F, Bilanges B, Hoffmann A, Pantaloni C, Bockaert J, Spengler D, Journot L. hZAC encodes a zinc finger protein with antiproliferative properties and maps to a chromosomal region frequently lost in cancer. Proc Natl Acad Sci U S A. 1998; 95:8835-40.

13. Vega-Benedetti AF, Saucedo C, Zavattari P, Vanni R, Zugaza JL, Parada LA. PLAGL1: an important player in diverse pathological processes. J Appl Genet. 2017; 58:71-8. https:// doi.org/10.1007/s13353-016-0355-4.

14. Huang SM, Schonthal AH, Stallcup MR. Enhancement of p53-dependent gene activation by the transcriptional coactivator Zac1. Oncogene. 2001; 20:2134-43. https://doi. org/10.1038/sj.onc. 1204298 .

15. Hoffmann A, Barz T, Spengler D. Multitasking $\mathrm{C} 2 \mathrm{H} 2$ zinc fingers link Zac DNA binding to coordinated regulation 
of p300-histone acetyltransferase activity. Mol Cell Biol. 2006; 26:5544-57. https://doi.org/10.1128/MCB.02270-05.

16. Hoffmann A, Spengler D. A new coactivator function for Zac1's C2H2 zinc finger DNA-binding domain in selectively controlling PCAF activity. Mol Cell Biol. 2008; 28:6078-93. https://doi.org/10.1128/MCB.00842-08.

17. Theodoropoulou M, Stalla GK, Spengler D. ZAC1 target genes and pituitary tumorigenesis. Mol Cell Endocrinol. 2010; 326:60-5. https://doi.org/10.1016/j.mce.2010.01.033.

18. Shen B, Chu ES, Zhao G, Man K, Wu CW, Cheng JT, Li G, Nie Y, Lo CM, Teoh N, Farrell GC, Sung JJ, Yu J. PPARgamma inhibits hepatocellular carcinoma metastases in vitro and in mice. Br J Cancer. 2012; 106:1486-94. https://doi.org/10.1038/bjc.2012.130.

19. Lemeta S, Salmenkivi K, Pylkkanen L, Sainio M, Saarikoski ST, Arola J, Heikkila P, Haglund C, HusgafvelPursiainen K, Bohling T. Frequent loss of heterozygosity at 6q in pheochromocytoma. Hum Pathol. 2006; 37:749-54. https://doi.org/10.1016/j.humpath.2006.02.002.

20. Cvetkovic D, Pisarcik D, Lee C, Hamilton TC, Abdollahi A. Altered expression and loss of heterozygosity of the LOT1 gene in ovarian cancer. Gynecol Oncol. 2004; 95:449-55. https://doi.org/10.1016/j.ygyno.2004.08.051.

21. Bilanges B, Varrault A, Basyuk E, Rodriguez C, Mazumdar A, Pantaloni C, Bockaert J, Theillet C, Spengler D, Journot L. Loss of expression of the candidate tumor suppressor gene ZAC in breast cancer cell lines and primary tumors. Oncogene. 1999; 18:3979-88. https://doi.org/10.1038/ sj.onc. 1202933.

22. Pagotto U, Arzberger T, Theodoropoulou M, Grubler Y, Pantaloni C, Saeger W, Losa M, Journot L, Stalla GK, Spengler D. The expression of the antiproliferative gene ZAC is lost or highly reduced in nonfunctioning pituitary adenomas. Cancer Res. 2000; 60:6794-9.

23. Lemeta S, Jarmalaite S, Pylkkanen L, Bohling T, HusgafvelPursiainen K. Preferential loss of the nonimprinted allele for the ZAC1 tumor suppressor gene in human capillary hemangioblastoma. J Neuropathol Exp Neurol. 2007; 66:860-7.

24. Vieria Neto L, Wildemberg LE, Colli LM, Kasuki L, Marques NV, Moraes AB, Gasparetto EL, Takiya CM, Castro M, Gadelha MR. ZAC1 and SSTR2 are downregulated in non-functioning pituitary adenomas but not in somatotropinomas. PLoS One. 2013; 8:e77406.

25. Kowalczyk AE, Krazinski BE, Godlewski J, Kiewisz J, Kwiatkowski P, Sliwinska-Jewsiewicka A, Kiezun J, Wierzbicki PM, Bodek G, Sulik M, Kmiec Z. Altered expression of the PLAGL1 (ZAC1/LOT1) gene in colorectal cancer: Correlations to the clinicopathological parameters. Int J Oncol. 2015; 47:951-62. https://doi. org/10.3892/ijo.2015.3067.

26. Midorikawa $\mathrm{Y}$, Yamamoto S, Ishikawa S, Kamimura N, Igarashi H, Sugimura H, Makuuchi M, Aburatani H. Molecular karyotyping of human hepatocellular carcinoma using single-nucleotide polymorphism arrays. Oncogene. 2006; 25:5581-90.
27. Abdollahi A, Roberts D, Godwin AK, Schultz DC, Sonoda G, Testa JR, Hamilton TC. Identification of a zincfinger gene at 6q25: a chromosomal region implicated in development of many solid tumors. Oncogene. 1997; 14:1973-9. https://doi.org/10.1038/sj.onc.1201034.

28. Hide T, Takezaki T, Nakatani Y, Nakamura H, Kuratsu J, Kondo T. Sox11 prevents tumorigenesis of glioma-initiating cells by inducing neuronal differentiation. Cancer Res. 2009; 69:7953-9.

29. Godlewski J, Krazinski BE, Kiezun J, Kwiatkowski P, Sulik M, Tenderenda M, Biernat W, Kmiec Z. PLAGL1 protein is differentially expressed in the nephron segments and collecting ducts in human kidney. Folia Histochem Cytobiol. 2015; 53:96-104. https://doi.org/10.5603/FHC. a2015.0011.

30. Abdollahi A. LOT1 (ZAC1/PLAGL1) and its family members: mechanisms and functions. J Cell Physiol. 2007; 210:16-25. https://doi.org/10.1002/jcp.20835.

31. Li Z, Ding Y, Zhu Y, Yin M, Le X, Wang L, Yang Y, Zhang Q. Both gene deletion and promoter hyper-methylation contribute to the down-regulation of ZAC/PLAGL1 gene in gastric adenocarcinomas: a case control study. Clin Res Hepatol Gastroenterol. 2014; 38:744-50.

32. Kakar S, Chen X, Ho C, Burgart LJ, Adeyi O, Jain D, Sahai V, Ferrell LD. Chromosomal abnormalities determined by comparative genomic hybridization are helpful in the diagnosis of atypical hepatocellular neoplasms. Histopathology. 2009; 55:197-205.

33. Jarmalaite S, Laurinaviciene A, Tverkuviene J, Kalinauskaite N, Petroska D, Bohling T, HusgafvelPursiainen K. Tumor suppressor gene ZAC/PLAGL1: altered expression and loss of the nonimprinted allele in pheochromocytomas. Cancer Genet. 2011; 204:398-404. https://doi.org/10.1016/j.cancergen.2011.07.002.

34. Vogel C, Marcotte EM. Insights into the regulation of protein abundance from proteomic and transcriptomic analyses. Nat Rev Genet. 2012; 13:227-32. https://doi. org/10.1038/nrg3185.

35. Joung JG, Kim D, Lee SY, Kang HJ, Kim JH. Integrated analysis of microRNA-target interactions with clinical outcomes for cancers. BMC Med Genomics. 2014; 7:S10. https://doi.org/10.1186/1755-8794-7-S1-S10.

36. Zhang S, Lu Z, Unruh AK, Ivan C, Baggerly KA, Calin GA, Li Z, Bast RC Jr, Le XF. Clinically relevant microRNAs in ovarian cancer. Mol Cancer Res. 2015; 13:393-401. https:// doi.org/10.1158/1541-7786.MCR-14-0424.

37. Royo F, Paz N, Espinosa L, McQueen PG, Vellon L, Parada LA. Spatial link between nucleoli and expression of the Zac1 gene. Chromosoma. 2009; 118:711-22. https://doi. org/10.1007/s00412-009-0229-1.

38. Huang SM, Huang SP, Wang SL, Liu PY. Importin alpha1 is involved in the nuclear localization of Zac1 and the induction of p21WAF1/CIP1 by Zac1. Biochem J. 2007; 402:359-66. 
39. Ortega JF, de Conti A, Tryndyak V, Furtado KS, Heidor R, Horst MA, Fernandes LH, Tavares PE, Pogribna M, Shpyleva S, Beland FA, Pogribny IP, Moreno FS. Suppressing activity of tributyrin on hepatocarcinogenesis is associated with inhibiting the p53-CRM1 interaction and changing the cellular compartmentalization of $\mathrm{p} 53$ protein. Oncotarget. 2016; 7:24339-47. https://doi.org/10.18632/ oncotarget.8248.

40. Rozenfeld-Granot G, Krishnamurthy J, Kannan K, Toren A, Amariglio N, Givol D, Rechavi G. A positive feedback mechanism in the transcriptional activation of Apaf-1 by p53 and the coactivator Zac-1. Oncogene. 2002; 21:146976. https://doi.org/10.1038/sj.onc.1205218.

41. Varrault A, Dantec C, Le Digarcher A, Chotard L, Bilanges B, Parrinello H, Dubois E, Rialle S, Severac D, Bouschet $\mathrm{T}$, Journot L. Identification of Plagl1/Zac1 binding sites and target genes establishes its role in the regulation of extracellular matrix genes and the imprinted gene network. Nucleic Acids Res. 2017; 45:10466-80.

42. Koga H, Sakisaka S, Harada M, Takagi T, Hanada S, Taniguchi E, Kawaguchi T, Sasatomi K, Kimura R, Hashimoto O, Ueno T, Yano H, Kojiro M, et al. Involvement of p21(WAF1/Cip1), p27(Kip1), and p18(INK4c) in troglitazone-induced cell-cycle arrest in human hepatoma cell lines. Hepatology. 2001; 33:1087-97.

43. Warfel NA, El-Deiry WS. p21WAF1 and tumourigenesis: 20 years after. Curr Opin Oncol. 2013; 25:52-8. https://doi. org/10.1097/CCO.0b013e32835b639e.

44. Yousefi B, Rahmati M, Ahmadi Y. The roles of p53R2 in cancer progression based on the new function of mutant $\mathrm{p} 53$ and cytoplasmic p21. Life Sci. 2014; 99:14-7.

45. Abbas T, Dutta A. p21 in cancer: intricate networks and multiple activities. Nat Rev Cancer. 2009; 9:400-14.

46. Machado-Silva A, Perrier S, Bourdon JC. p53 family members in cancer diagnosis and treatment. Semin Cancer Biol. 2010; 20:57-62.

47. Barz T, Hoffmann A, Panhuysen M, Spengler D. Peroxisome proliferator-activated receptor gamma is a $\mathrm{Zac}$ target gene mediating Zac antiproliferation. Cancer Res. 2006; 66:11975-82.

48. Liu PY, Hsieh TY, Liu ST, Chang YL, Lin WS, Wang WM, Huang SM. Zac1, an Sp1-like protein, regulates human p21(WAF1/Cip1) gene expression in HeLa cells. Exp Cell Res. 2011; 317:2925-37. https://doi.org/10.1016/j. yexcr.2011.09.018.
49. Panigrahy D, Shen LQ, Kieran MW, Kaipainen A. Therapeutic potential of thiazolidinediones as anticancer agents. Expert Opin Investig Drugs. 2003; 12:1925-37. https://doi.org/10.1517/13543784.12.12.1925.

50. Tsubouchi Y, Sano H, Kawahito Y, Mukai S, Yamada R, Kohno M, Inoue K, Hla T, Kondo M. Inhibition of human lung cancer cell growth by the peroxisome proliferatoractivated receptor-gamma agonists through induction of apoptosis. Biochem Biophys Res Commun. 2000; 270:400-5.

51. Bonofiglio D, Qi H, Gabriele S, Catalano S, Aquila S, Belmonte M, Ando S. Peroxisome proliferator-activated receptor gamma inhibits follicular and anaplastic thyroid carcinoma cells growth by upregulating p21Cip1/WAF1 gene in a Sp1-dependent manner. Endocr Relat Cancer. 2008; 15:545-57.

52. Schaefer KL, Wada K, Takahashi H, Matsuhashi N, Ohnishi S, Wolfe MM, Turner JR, Nakajima A, Borkan SC, Saubermann LJ. Peroxisome proliferator-activated receptor gamma inhibition prevents adhesion to the extracellular matrix and induces anoikis in hepatocellular carcinoma cells. Cancer Res. 2005; 65:2251-9.

53. Yu J, Shen B, Chu ES, Teoh N, Cheung KF, Wu CW, Wang S, Lam CN, Feng H, Zhao J, Cheng AS, To KF, Chan HL, et al. Inhibitory role of peroxisome proliferatoractivated receptor gamma in hepatocarcinogenesis in mice and in vitro. Hepatology. 2010; 51:2008-19. https://doi. org/10.1002/hep.23550.

54. Royo F, Zabala A, Paz N, Acquadro F, Echevarria JJ, Zabalza I, Cigudosa JC, Zugaza JL, Parada LA. Genome-wide analysis of DNA copy number changes in liver steatosis. Br J Med Med Res. 2013; 3:1773-85. https://doi.org/10.9734/ BJMMR/2013/2543.

55. Leal M, Lima E, Silva P, Assumpcao P, Calcagno D, Payao S, Burbano RR, Smith M. Promoter hypermethylation of CDH1, FHIT, MTAP and PLAGL1 in gastric adenocarcinoma in individuals from Northern Brazil. World J Gastroenterol. 2007; 13:2568-74.

56. Bilanges B, Varrault A, Mazumdar A, Pantaloni C, Hoffmann A, Bockaert J, Spengler D, Journot L. Alternative splicing of the imprinted candidate tumor suppressor gene ZAC regulates its antiproliferative and DNA binding activities. Oncogene. 2001; 20:1246-53. https://doi. org/10.1038/sj.onc. 1204237 . 